Prepared in cooperation with the U.S. Department of Energy Office of Environmental Management, National Nuclear Security Administration, Nevada Site Office, under Interagency Agreement DE-A152-01NV13944 and Office of Repository Development, under Interagency Agreement DE-A108-02RW12167

\title{
A Guide for Using the Transient Ground-Water Flow Model of the Death Valley Regional Ground-Water Flow System, Nevada and California
}

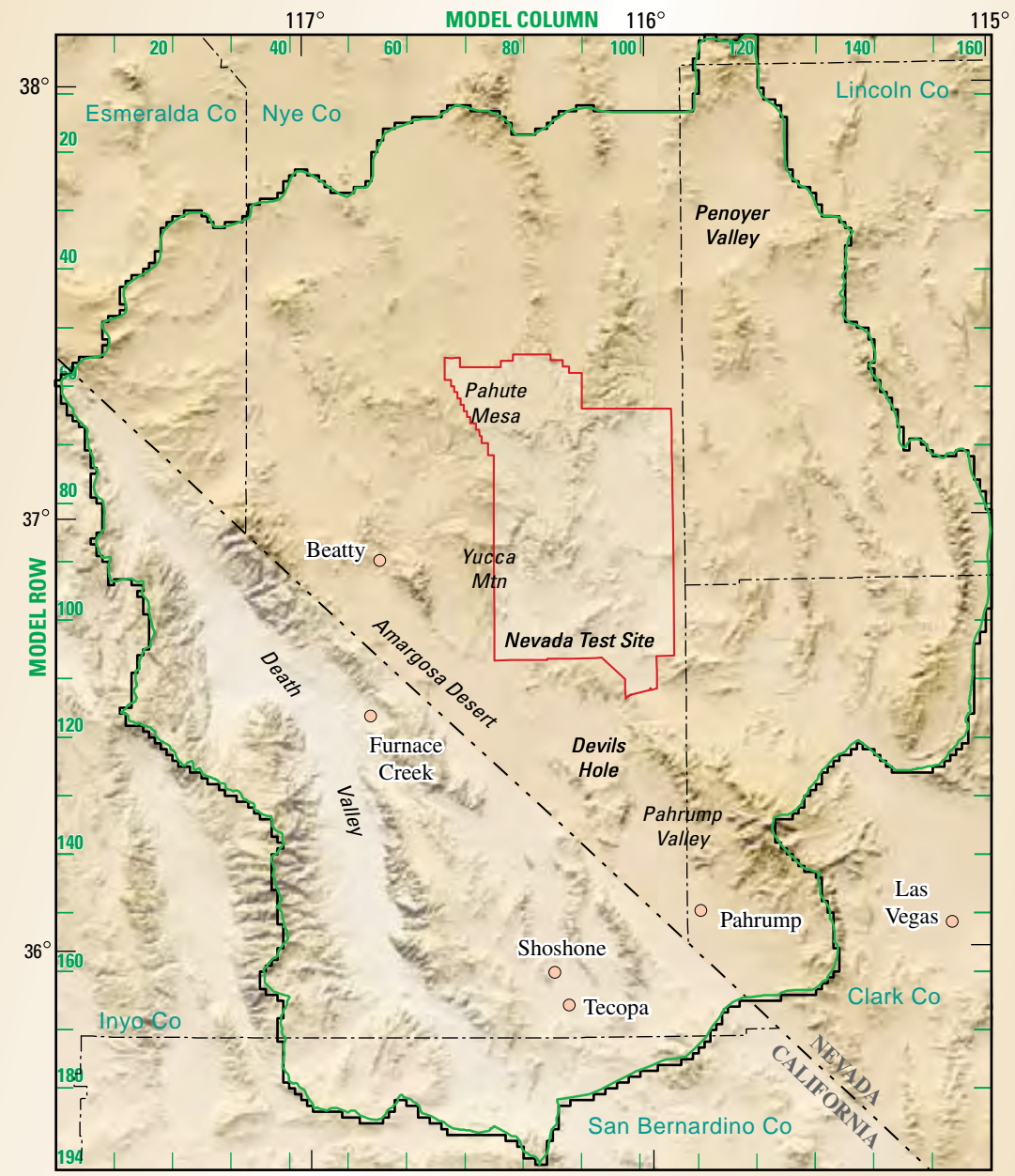

Open-File Report 2006-1104

U.S. Department of the Interior

U.S. Geological Survey 



\section{A Guide for Using the Transient Ground- Water Flow Model of the Death Valley Regional Ground-Water Flow System, Nevada and California}

By Joan B. Blainey, Claudia C. Faunt, and Mary C. Hill

Prepared in cooperation with the U.S. Department of Energy Office of Environmental

Management, National Nuclear Security Administration, Nevada Site Office, under Interagency

Agreement DE-A152-01NV13944 and Office of Repository Development, under Interagency

Agreement DE-A108-02RW12167

Open-File Report 2006-1104 


\section{U.S. Department of the Interior \\ P. Lynn Scarlett, Acting Secretary}

\section{U.S. Geological Survey \\ P. Patrick Leahy, Acting Director}

U.S. Geological Survey, Reston, Virginia: 2006

For sale by U.S. Geological Survey, Information Services
Box 25286, Denver Federal Center
Denver, CO 80225
For more information about the USGS and its products:
Telephone: 1-888-ASK-USGS
World Wide Web: http://www.usgs.gov/

Any use of trade, product, or firm names in this publication is for descriptive purposes only and does not imply endorsement by the U.S. Government.

Although this report is in the public domain, permission must be secured from the individual copyright owners to reproduce any copyrighted materials contained within this report.

Suggested citation:

Blainey, J.B., Faunt, C.C., and Hill, M.C., 2006, A guide for using the transient ground-water flow model of the Death Valley regional ground-water flow system, Nevada and California: U.S. Geological Survey Open-File Report 2006-1104, 26 p. Available at URL: <http://pubs.water.usgs.gov/ofr2006-1104>. 


\section{Contents}

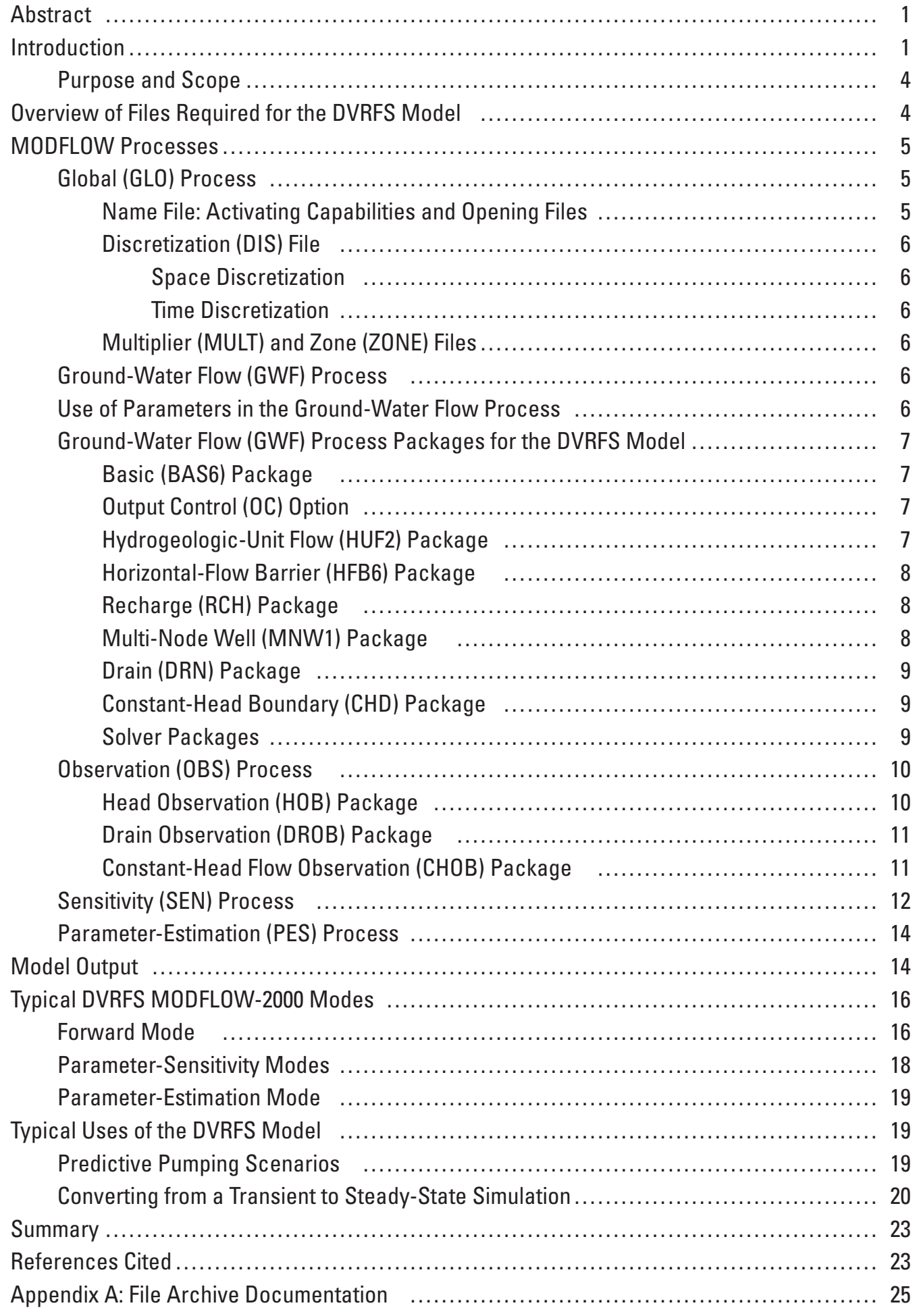




\section{Figures}

Figure 1. Map showing geographic and prominent topographic features of the Death Valley regional ground-water flow system, Nevada and California

Figure 2. Map showing simulated discharge areas, major recharge areas, constant-head boundary flows, and steady-state stress period hydraulic head in the uppermost active model layer of the Death Valley regional ground-water flow system, Nevada and California

Figure 3. Graph showing annual discharge from Bennetts and Manse springs in Pahrump Valley, Nevada, 1875-1998

\section{Tables}

Table 1. MODFLOW-2000 packages and processes used in the Death Valley regional ground-water flow system model, Nevada and California

Table 2. Map coordinates for the Death Valley regional ground-water flow system, Nevada and California

Table 3. Description of the parameter names in the sensitivity file and the associated packages and files

Table 4. Sensitivity Process and associated factors for Constant-Head Boundary, Drain, Horizontal-Flow Barrier, and Recharge Packages

Table 5. Select output files produced by MODFLOW-2000 by active processes

Table 6. Plot symbol codes that identify the observation type in all "underscore" output files created during forward and parameter-sensitivity mode simulations

Table 7. Modes of MODFLOW-2000 produced by activating different combinations of the Sensitivity and Parameter-Estimation Processes, and commonly used output when the Observation Process is active 


\section{Conversion Factors, Datums, and Abbreviations and Acronyms}

SI to Inch/Pound

\begin{tabular}{lcl}
\hline Multiply & By & To obtain \\
\hline cubic meter per day $\left(\mathrm{m}^{3} / \mathrm{d}\right)$ & 0.2961 & acre-foot per year \\
cubic meter per day $\left(\mathrm{m}^{3} / \mathrm{d}\right)$ & 0.0004087 & cubic foot per second \\
cubic meter per day $\left(\mathrm{m}^{3} / \mathrm{d}\right)$ & 264.2 & gallon per day \\
kilometer $(\mathrm{km})$ & 0.6214 & mile \\
meter $(\mathrm{m})$ & 3.281 & foot \\
meter per day $(\mathrm{m} / \mathrm{d})$ & 3.281 & foot per day \\
meter per day per meter $[(\mathrm{m} / \mathrm{d}) / \mathrm{m}]$ & 1 & foot per day per foot \\
square kilometer $\left(\mathrm{km}^{2}\right)$ & 2.417 & acre \\
square kilometer $\left(\mathrm{km}^{2}\right)$ & 0.3861 & square mile \\
\hline
\end{tabular}

Datums

Vertical coordinate information is referenced to the North American Vertical Datum of 1988 (NAVD 88).

Horizontal coordinate information is referenced to the North American Datum of 1927 (NAD 27).

Altitude, as used in this report, refers to distance above the vertical datum. 


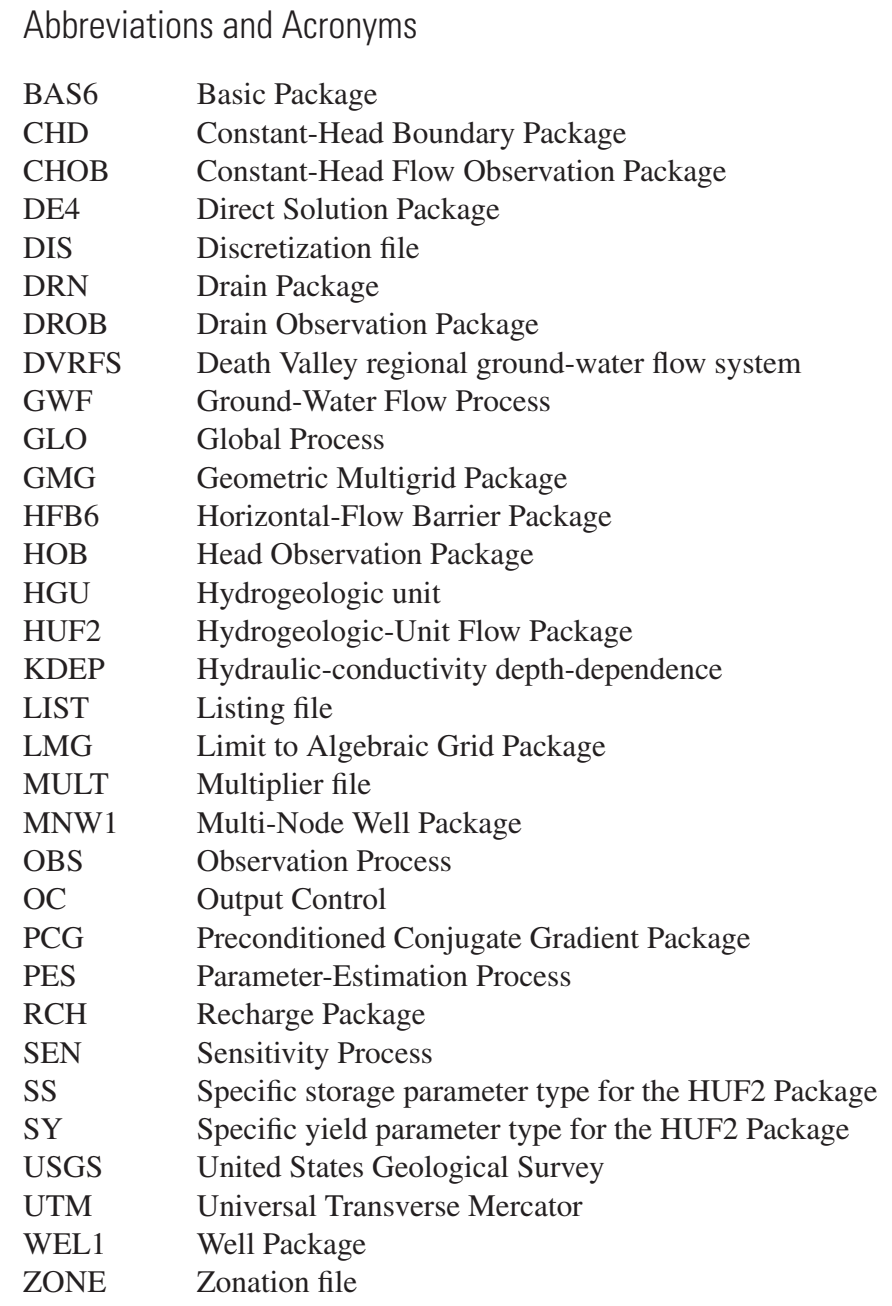




\title{
A Guide for Using the Transient Ground-Water Flow Model of the Death Valley Regional Ground-Water Flow System, Nevada and California
}

\author{
By Joan B. Blainey, Claudia C. Faunt, and Mary C. Hill
}

\begin{abstract}
This report is a guide for executing numerical simulations with the transient ground-water flow model of the Death Valley regional ground-water flow system, Nevada and California using the U.S. Geological Survey modular finitedifference ground-water flow model, MODFLOW-2000. Model inputs, including observations of hydraulic head, discharge, and boundary flows, are summarized. Modification of the DVRFS transient ground-water model is discussed for two common uses of the Death Valley regional ground-water flow system model: predictive pumping scenarios that extend beyond the end of the model simulation period (1998), and model simulations with only steady-state conditions.
\end{abstract}

\section{Introduction}

The Death Valley regional ground-water flow system (DVRFS) model domain encompasses about $100,000 \mathrm{~km}^{2}$ in Nevada and California and is bounded by latitudes $35^{\circ} 00^{\prime} \mathrm{N}$ and $38^{\circ} 15^{\prime} \mathrm{N}$ and by longitudes $115^{\circ} 00^{\prime} \mathrm{W}$ and $118^{\circ} 00^{\prime} \mathrm{W}$ (fig. 1). Belcher and others (2004), San Juan and others (2004), and Faunt and others (2004a, 2004b) documented the development of a conceptual understanding of the system hydrology and hydrogeology, and ultimately a transient ground-water simulation of the DVRFS. Faunt and others (2004a) and San Juan and others (2004) described the conceptualization of the system hydrology, natural groundwater discharge including evapotranspiration and springs, pumpage, ground-water recharge, and water levels (fig. 2). In particular, San Juan and others (2004) described model inputs and their sources, including the calculation of observations (water levels, flows at the model boundary, and natural discharge) and observation weights. These observations and the associated weights form the basis of the data used to calibrate and evaluate the transient numerical flow model.
The transient ground-water flow model of the DVRFS simulates steady-state conditions that represent predevelopment conditions followed by transient conditions from 1913 through 1998 (Faunt and others, 2004b). Recharge is constant at average annual values for the entire period of simulation; however, the simulated recharge varies spatially. Ground-water pumpage from 1913 to 1998 is a transient stress imposed using average annual values. Along some portions of the model boundary, constant-head boundary flows represent lateral flow from adjacent basins. Ground-water discharge from evapotranspiration and spring flow is simulated using head-dependent boundaries. DVRFS model input, output, and source code are available at the model archive link at URL: http://pubs.water.usgs.gov/sir20045205/ (accessed on December 22, 2005). A complete list and description of the archived model files are provided in the Appendix A (at back of report).

The DVRFS model uses the Ground-Water Flow Process of MODFLOW-2000 [which is similar to the capabilities of MODFLOW-96 (Harbaugh and McDonald, 1996)], as well as the Observation and Sensitivity-Analysis Processes of MODFLOW-2000 (Hill, 1990; Harbaugh and others, 2000; Hill and others, 2000). Subsequent to these publications, additional MODFLOW capabilities were developed and used in the DVRFS model including the Hydrogeologic-Unit Flow (HUF2) Package (Anderman and Hill, 2000, 2003) and the Multi-Node Well (MNW1) Package (Halford and Hanson, 2002). The HUF2 Package allows the modeler to translate the hydrogeologic framework into flow model layers by defining the geometry of the hydrogeologic units independently of the flow model layers. The MNW1 Package simulates pumping and injection for wells that penetrate multiple flow model layers. 


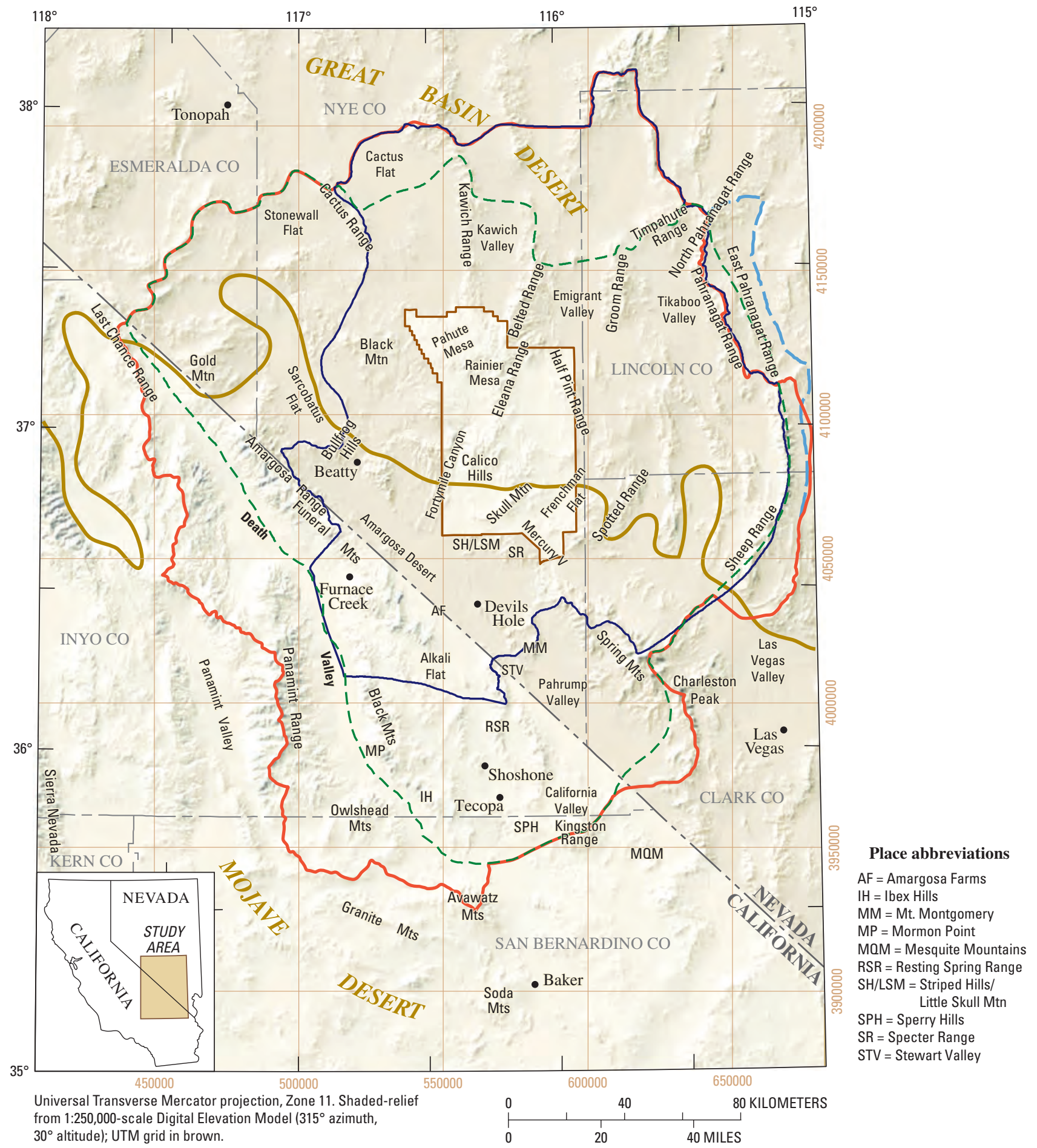

EXPLANATION
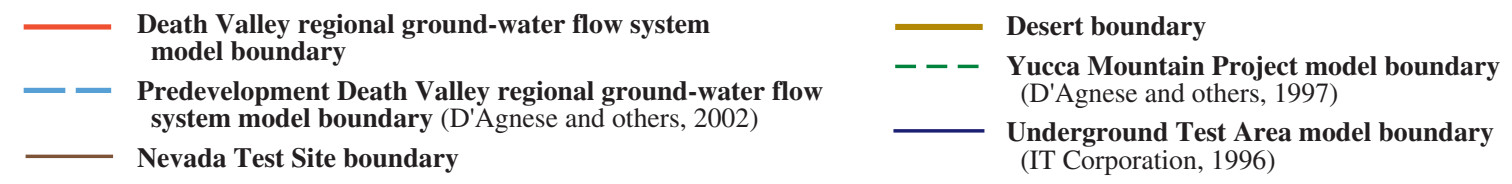

Figure 1. Geographic and prominent topographic features of the Death Valley regional ground-water flow system, Nevada and California. 


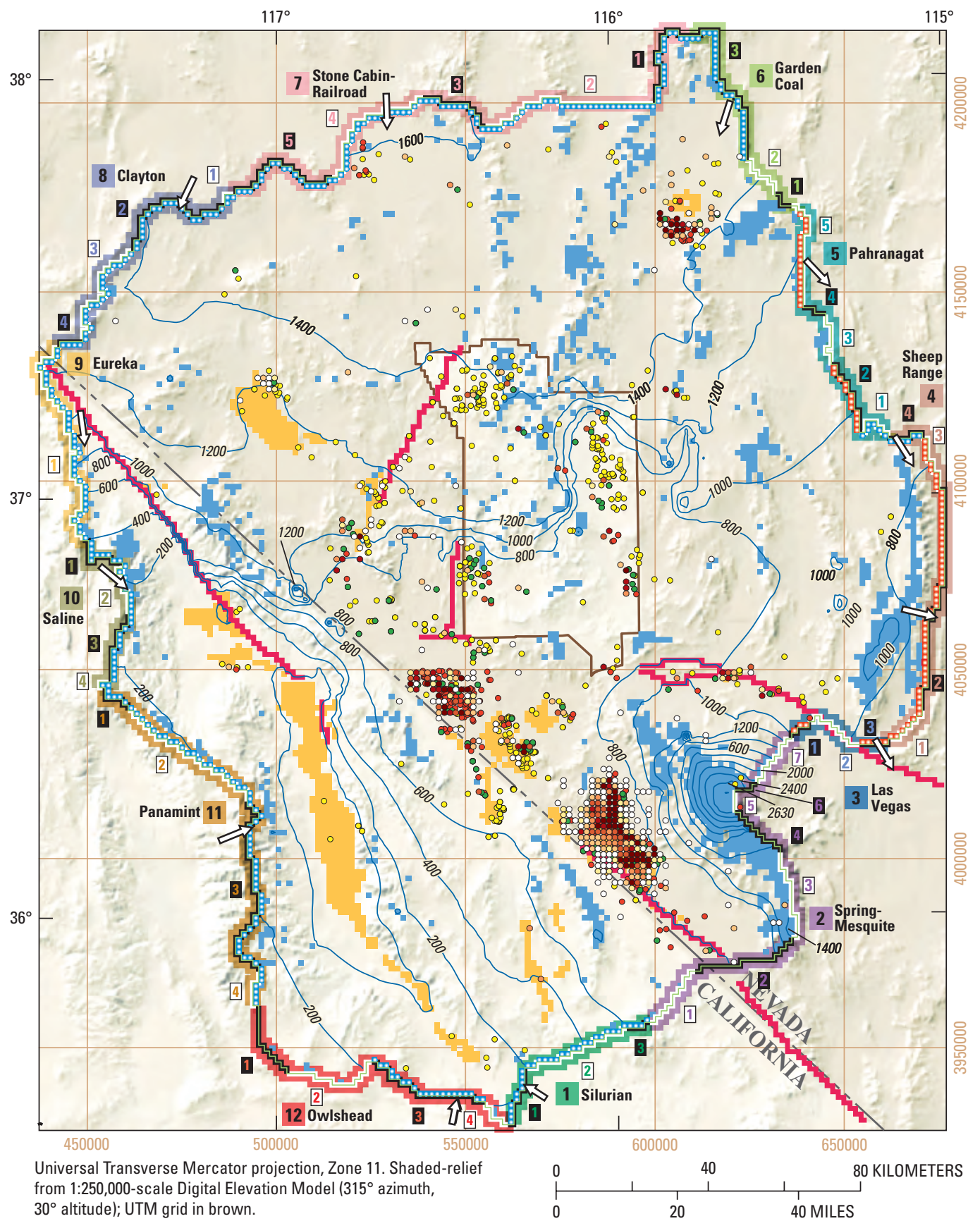

from 1:250,000-scale Digital Elevation Model $\left(315^{\circ}\right.$ azimuth $30^{\circ}$ altitude); UTM grid in brown.

\section{EXPLANATION}
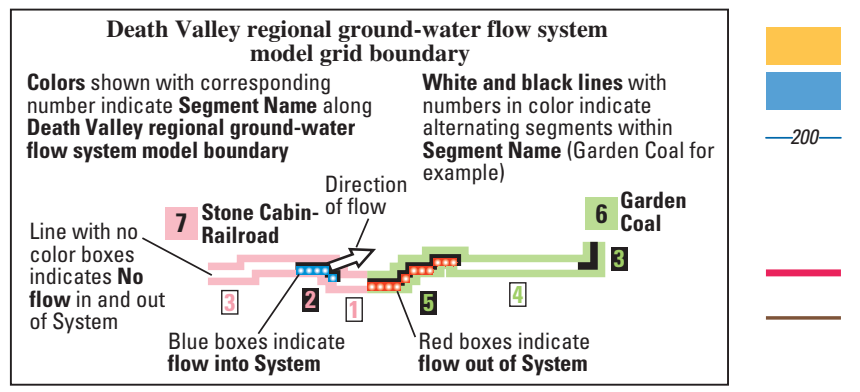

Simulated discharge areas

Simulated major recharge areas

Simulated steady-state potentiometricsurface contour for layer 1 -Contour interval is 200 meters. Datum is North American Vertical Datum, 1988

Simulated horizontal-flow barriers

Nevada Test Site boundary
Simulated pumping well and total withdrawal by model cell, in cubic meters per day (1913-98)

- Less than 50,000

- 50,000 to 100,000

- 100,000 to 500,000

- 500,000 to $1,000,000$

- $1,000,000$ to $5,000,000$

- $5,000,000$ to $10,000,000$

- Greater than $10,000,000$

Figure 2. Simulated discharge areas, major recharge areas, constant-head boundary flows, and steady-state stress period hydraulic head in the uppermost active model layer of the Death Valley regional ground-water flow system, Nevada and California. 


\section{Purpose and Scope}

This report provides the user of the DVRFS transient ground-water model a guide for conducting numerical simulations with the archived model using MODFLOW2000 (Harbaugh and others, 2000; Hill and others, 2000). Both model input and output will be described for forward, sensitivity-analysis, and parameter estimation model simulations. Additionally, modification of the DVRFS transient ground-water model is discussed for two common uses of the DVRFS model: predictive pumping scenarios that extend beyond the end of the model simulation period (1998), and model simulations with only steady-state simulation. For both of these model modifications, the required editing of MODFLOW-2000 input, including observation files, is outlined with examples. This report is designed for users familiar with concepts associated with the Ground-Water Flow Process of MODFLOW-2000 [which is similar to the capabilities of MODFLOW-96 (Harbaugh and McDonald, 1996)] but perhaps less familiar with the Observation, Sensitivity-Analysis, and Parameter-Estimation Processes of MODFLOW-2000 (Hill, 1990; Harbaugh and others, 2000; Hill and others, 2000).

\section{Overview of Files Required for the DVRFS Model}

All necessary DVRFS model input is read from one or more input data files. MODFLOW-2000 reads ASCII files and outputs ASCII (and in some cases binary) files. Input required for conducting MODFLOW-2000 simulations with the DVRFS model for the Observation, Sensitivity, and ParameterEstimation Processes are shown in table 1.

Table 1. MODFLOW-2000 packages and processes used in the Death Valley regional ground-water flow system model, Nevada and California.

[Package or process: BAS6, Basic Package; CHD, Constant-Head Boundary Package; DRN, Drain Package; GLO, Global Process; GWF, Ground-water Flow Process; HFB6, Horizontal-Flow Barrier Package; HUF2, Hydrogeologic Unit Flow Package; MNW1, Multi-Node Well Package; OBS, Observation Process; PCG2, Preconditioned Conjugate-Gradient Package; PES, Parameter-Estimation Process; RCH, Recharge Package; SEN, Sensitivity Process; ZONE, zone file]

\begin{tabular}{|c|c|c|c|}
\hline Package or process & $\begin{array}{c}\text { Package or } \\
\text { process file type }\end{array}$ & Input file name & Reference \\
\hline $\begin{array}{l}\text { Global Process (including the discretization } \\
\text { file (DIS), multiplier file (MULT), name, } \\
\text { and ZONE files and utility modules) }\end{array}$ & GLO & $\begin{array}{l}\text { DIS_WT_CONFINED.txt, MULT.txt, } \\
\text { NAME.txt, ZONE.txt }\end{array}$ & Harbaugh and others (2000) \\
\hline $\begin{array}{l}\text { Groundwater Flow Process [including the } \\
\text { Output Control Option (OC)] }\end{array}$ & GWF & OC.txt & Harbaugh and others (2000) \\
\hline Horizontal-Flow Barrier Package & HFB6 & HFB_final_tr.txt & Harbaugh and others (2000) \\
\hline Recharge Package & $\mathrm{RCH}$ & RCH_tr.txt & Harbaugh and others (2000) \\
\hline Multi-Node Well Package & MNW1 & MNW_withdrawal_1_7_20.txt ${ }^{1}$ & Halford and Hanson (2002) \\
\hline Drain Package & DRN & DRN_tr.txt & Harbaugh and others (2000) \\
\hline Constant-Head Boundary Package & CHD & CHD_15reg_tr.txt & Harbaugh and others (2000) \\
\hline Sensitivity Process & SEN & SENSITIVITY.txt & Hill and others (2000) \\
\hline Parameter-Estimation Process & PES & PES.txt & Hill and others (2000) \\
\hline
\end{tabular}

\footnotetext{
${ }^{1}$ The MNW1 Package has an option to create an equivalent file in the WEL1 Package format. This file, wel_package.wl1, is included in the model archive.
} 
The required input, which is organized into groups of related data sets and packages, varies according to the active MODFLOW-2000 capabilities. A single model simulation or parameter-estimation simulation will not use all files, packages, or processes available. Information produced by MODFLOW-2000 is written to one or more output data files. Input and output are stored in ASCII files or in some cases binary files. These files are designed to be read by programs such as text editors, and plotting or data analysis routines (Harbaugh, 1990; Hanson and Leake, 1999; Winston, 2000). Archived input files for the DVRFS model are:

- Input and output control information [name and Output Control (OC) files].

- Finite-difference grid and time discretization [Basic (BAS6) Package and Discretization (DIS) File].

- Multiplier (MULT) file.

- Zone (ZONE) file.

- Initial conditions (BAS6 Package).

- Properties of the porous media [Hydrogeologic-Unit Flow (HUF2) Package].

- Horizontal-Flow Barrier (HFB6) Package.

- Source term packages:

- Head-independent packages [Well (WEL1), Recharge (RCH), and Multi-Node Well (MNW1) Packages].

- Head-dependent package [Drain (DRN) Package].

- Time-Variant Specified Head-Package [Constant-Head Boundary (CHD) Package).

- Solver (Preconditioned Conjugate Gradient (PCG2) Package].

- Utilities for reading array and list data (U2DREL).

- Observation Process (OBS) and Observation Packages [Head Observation (HOB), Drain Observation (DROB), and Constant-Head Flow Observation (CHOB) Packages].

- Sensitivity (SEN) Process.

- Parameter-Estimation (PES) Process.

\section{MODFLOW Processes}

MODFLOW is a computer program that simulates three-dimensional ground-water flow through porous media using the finite-difference method (McDonald and Harbaugh, 1984, 1988). Each process of MODFLOW-2000, the most recent version of MODFLOW, solves an equation with the exception of the Global (GLO) Process. The five processes of MODFLOW-2000 are: Global (GLO) Process, Ground-Water Flow (GWF) Process, Observation (OBS) Process, Sensitivity (SEN) Process, and Parameter-Estimation (PES) Process.

In the GLO Process, input arrays define the physical system including the altitude and spatial discretization. Input data files also describe the model grid geometry, layers, time discretization, and program operation. Data describing the physical properties of the media and the ground-water flow system are input through the various packages of the GWF Process. Finite-difference equations are solved by the GWF Process to compute a hydraulic head solution based on the active processes and packages. Simulated values may be compared to observations in the OBS Process. Various statistics and sensitivities to the observations are calculated in the OBS Process. Upon user initiation, the sensitivity equation for hydraulic heads with respect to each parameter is calculated throughout the model grid by the SEN Process. If both the OBS and SEN Processes are active, observation sensitivities may be calculated. With the PES Process active, parameter estimation may determine parameter values based on optimization of a weighted least-squares objective function that evaluates the fit of simulated values to the observations.

\section{Global (GLO) Process}

The GLO Process controls overall program flow, opens files, and reads global data such as space and time discretization. The GLO Process has four input files: name, discretization, multiplier, and zone files. Instructions for preparing the name file, and explanations for the variables read in all other files except as noted, are included in the Input Instructions section of Harbaugh and others (2000).

\section{Name File: Activating Capabilities and Opening Files}

The name file controls the capabilities of MODFLOW2000 utilized during a model simulation. The name file lists most of the files used by the GLO, OBS, SEN, and PES Processes. MODFLOW capabilities are activated by listing the appropriate file type along with the file name and unit number. A process or file is not active if a "\#” sign appears in the first column of the line in the name file (name.txt). 


\section{Discretization (DIS) File}

Both space and time information are discretized using information from the Discretization File, specified as file type "DIS". The length and time units of the model can be specified in the discretization file. In the DVRFS model, these units are meters and days.

\section{Space Discretization}

Information in the DIS file defines the physical size of the finite-difference grid. The model grid boundary is rectangular. Although the grid can be distorted vertically, model layers cannot pinch out to zero thickness.

The DVRFS model grid is oriented north-south and consists of 194 rows and 160 columns with a constant gridcell spacing of 1,500 by $1,500 \mathrm{~m}$ (fig. 2 and table 2 ). Each of the 16 model layers generally range in thickness from 50 to $300 \mathrm{~m}$ with model thickness generally increasing with depth (Faunt and others, 2004b, table F-1, p. 268). The upper model layers simulate relatively shallow saturated ground-water flow primarily through basin-fill sediments, volcanic rocks, and adjacent mountain ranges. Lower model layers predominantly simulate deep ground-water flow through the regional carbonate-rock aquifer beneath the basin fill and mountain ranges.

\section{Time Discretization}

Time discretization also is specified in the DIS file. The fundamental component of time discretization is the time step. Time steps are aggregated into stress periods. Time dependent input data can vary every stress period. Individual stress periods within a single simulation may be either transient or steady state. For each stress period, the user specifies the stress period length, the number of time steps, and the multiplier for the length of successive time steps. For transient stress periods, the number of time steps and the time step multiplier can affect the accuracy of the solution. The DVRFS model is

Table 2. Map coordinates for the Death Valley regional ground-water flow system, Nevada and California.

[Coordinates are calculated at the corner of the finite-difference model grid. Coordinates are in Universal Transverse Mercator, Zone 11]

\begin{tabular}{lccc}
\hline \multirow{2}{*}{$\begin{array}{c}\text { Corner of } \\
\text { model grid }\end{array}$} & $\begin{array}{c}\text { Grid node } \\
\text { (row, column) }\end{array}$ & \multicolumn{2}{c}{ Coordinates (meters) } \\
\cline { 3 - 4 } & & Northing & Easting \\
\hline Upper left & 1,1 & 437,000 & $4,219,000$ \\
Upper right & 1,160 & 677,000 & $4,219,000$ \\
Lower left & 194,1 & 437,000 & $3,928,000$ \\
Lower right & 194,160 & 677,000 & $3,928,000$ \\
\hline
\end{tabular}

structured with an initial steady-state stress period followed by 86 transient stress periods, each one year in duration. Each yearly stress period has two time steps. Simulations with more time steps did not improve model accuracy (Faunt and others, 2004b, p. 266).

\section{Multiplier (MULT) and Zone (ZONE) Files}

The multiplier file, specified as file type "MULT", defines multiplier arrays for calculation of model-layer characteristics from parameter values. Parameters are defined in section, "Use of Parameters in the Ground-Water Flow (GWF) Process." The multiplier file may be used to construct new arrays by adding and multiplying existing arrays. For the DVRFS model, the MULT file is used to represent an infiltration array, which is a multiplier for the Recharge Package.

The zone file, specified as file type "ZONE," defines arrays of different zones. Zone arrays may specify cells in a layer variable associated with a specific parameter. Parameters may be composed of either one or many zones. The DVRFS model uses many zone arrays to represent areas of similar porous media properties for a given hydrogeologic unit.

\section{Ground-Water Flow (GWF) Process}

The GWF Process includes all aspects of solving the ground-water flow equation, including formulation of the finite-difference equations, data input, solving the resulting simultaneous equations, and model output. The GWF Process uses the finite-difference method in which the ground-water flow system is divided into a grid of cells. At the center of each cell, or node, the finite-difference method is used to define a set of simultaneous equations, which are solved for head. For steady-state stress periods, the storage term in the ground-water flow equation is set to zero.

\section{Use of Parameters in the Ground-Water Flow Process}

With MODFLOW-2000, parameters may be used to define many of the numerous data values that must be specified for each model cell. A parameter is a single value that is used to determine data values for multiple cells. Parameter definition includes a parameter name and value, and the cells for which the input values are calculated using that parameter. The most common and direct approach for determining data values from parameters is to set the data value equal to the parameter value for multiple cells. In a more complex approach, data values are assigned for multiple cells with additive contributions from multiple parameters 
(Harbaugh and others, 2000, p. 14-19). The DVRFS model does not use additive parameters, but in some cases, such as the recharge parameters, the data value at a cell is equal to a parameter value times a value in a multiplication array. Cellby-cell model input used in MODFLOW 2000 calculations is a combination of parameter values specified in the package in which the parameters are defined and parameter values specified in the SEN Process, and possibly values specified in the zone and/or multiplier arrays.

\section{Ground-Water Flow (GWF) Process Packages for the DVRFS Model}

Harbaugh and others (2000) document the 15 packages included in the initial release of MODFLOW-2000. The DVRFS model includes 2 packages developed after the initial release of MODFLOW-2000: the internal flow package, HUF2, (Anderman and Hill, 2000, 2003) and the MNW1 Package (Halford and Hanson, 2002). The DVRFS model uses the Output Control Option and 8 GWF packages:

1. Basic (BAS6) Package;

2. Output Control (OC) Option;

3. Hydrogeologic-Unit Flow (HUF2) Package;

4. Horizontal-Flow Barrier (HFB6) Package;

5. Recharge $(\mathrm{RCH})$ Package;

6. Multi-Node Well (MNW1) Package or the Well (WEL1) Package);

7. Drain (DRN) Package;

8. Constant-Head Boundary (CHD) Package; and

9. Solver (Preconditioned Conjugate Gradient Package (PCG2)) Package.

\section{Basic (BAS6) Package}

The Basic Package, specified as file type "BAS6", defines the initial conditions and some of the boundary conditions of the model. Initial conditions consist of starting heads for each cell in all model layers. Boundary conditions are specified using the array IBOUND. The value of the IBOUND array is defined at each cell to indicate that (1) the cell is active and head in the cell will be calculated (for a variable-head cell, value $=1)$; (2) the cell is active and head should not change from a user-specified value (for a constant- or specified-head cell, value $=-1$ ); or (3) the cell is inactive and water cannot flow through the cell (for a no-flow cell, value $=0$ ).

\section{Output Control (OC) Option}

The Output Control Option, specified as file type "OC", is used in conjunction with flags in other packages to write head, drawdown, and budget information into separate files for specified time steps and stress periods. The OC Option overwrites the default for writing heads and the water budget to the listing file.

In the DVRFS model, head, drawdown, and budget information is printed and saved for the initial steady-state stress period and for stress periods 44 and 86 of the transient simulation. Stress period 44 is a mid-simulation stress period and stress period 86 (representing 1997) is the nextto-last stress period. Head and drawdown information is written to data files HEADSOUT.txt (unit number 46) and DRAWDOUT.txt (unit number 47).

\section{Hydrogeologic-Unit Flow (HUF2) Package}

The Hydrogeologic-Unit Flow (HUF2) Package, specified as file type "HUF2", is an internal-flow package as are the Layer-Property Flow Package (Harbaugh and others, 2000) and the Block-Centered Flow Package (McDonald and Harbaugh, 1988). Internal-flow packages calculate hydraulic conductance between cell centers. The HUF2 Package translates the hydrogeologic framework into flow model layers by optionally defining the geometry of the hydrogeologic units (HGUs) independently of flow model layers. In the DVRFS model, geometries of the HGUs are complex because of considerable structural deformation, which includes folding and faulting; model layers in the DVRFS model generally do not coincide with HGUs.

The HUF2 Package calculates effective hydraulic properties for all model layers based on hydraulic properties of the HGUs. The HUF2 Package determines which HGUs apply to a model layer for each flow model grid cell, and calculates model-layer horizontal hydraulic conductance using arithmetic averaging, vertical hydraulic conductance using harmonic averaging, and specific storage using arithmetic averaging (Anderman and Hill, 2000, p. 7-10).

Within a DVRFS model simulation, aquifer transmissivity was not changed as water levels declined because changes in the saturated thickness were small. This condition is documented and specified as the "confined" option in the HUF2 Package. Storage values were assigned to the top model layer, independent of HGU (Anderman and Hill, 2003, p. 4) using the parameter type SYTP. The storage coefficient of the top model layer is not multiplied by model layer thickness. 
With the HUF2 Package, horizontal hydraulic conductivity can be simulated as decreasing with depth exponentially using a variable (KDEP) that represents the depth decay coefficient (Anderman and Hill, 2003 p. 1618). Simulations with depth decay result in relatively more permeable values near the land surface and less permeable values at depth within a single $\mathrm{HGU}$ or in a portion (or zone) of an HGU. Values of the depth decay coefficients used in the DVRFS model result in substantially reduced hydraulic conductivity at depth for most HGUs (Faunt and others, 2004b, fig. F-35, p. 322).

\section{Horizontal-Flow Barrier (HFB6) Package}

Many fault zones contain a core of low permeability gouge, the locus of fault displacement, which acts as a barrier to ground-water flow. The capability to simulate thin, vertical, and low-permeability geologic features is part of the Horizontal-Flow Barrier Package (Hsieh and Freckleton, 1993), specified as file type "HFB6". The HFB6 Package simulates a ground-water barrier, which is located on the boundary between two adjacent finite-difference cells in the same layer, by adjusting the hydraulic conductance between adjacent cells.

In the DVRFS model, oftentimes juxtaposition of HGUs effectively represented a flow barrier because hydraulic properties differed greatly between HGUs. Consequently, the barrier to flow did not need to be represented with a hydraulic barrier in the HFB6 Package. In some cases, important regional faults that influence ground-water flow were incorporated into the affected HGUs. For example, thrust faults can create a stratigraphic repetition of HGUs that can create sharp contrasts in hydraulic conductivity (Faunt and others, 2004b, p. 181). Structures interpreted as thin, vertical, low-permeability features were represented as $1 \mathrm{~m}$ wide (Faunt and others, 2004b, p. 269) using the HFB6 Package. HFB6 parameters with little influence on the simulation of head and discharge were removed from the model during calibration. Consequently, there are nine HFB6 parameters in the DVRFS model that represent eight important regional faults (Faunt and others, 2004b table F-15, p. 324 and fig. F-5, p. 273).

\section{Recharge (RCH) Package}

The Recharge Package, specified as file type "RCH", simulates areally distributed recharge to the ground-water system from precipitation that percolates through the unsaturated zone to the ground-water system. Distributed recharge for the DVRFS model is based on a spatially distributed hydrologic model of net infiltration (Hevesi and others, 2003). The net infiltration model simulates a daily water balance in the unsaturated zone to a maximum depth of $6 \mathrm{~m}$, the depth at which the seasonal effects of evapotranspiration become insignificant (San Juan and others, 2004, p. 115-118). Net infiltration is a reasonable approximation of ground-water recharge because most of the net infiltration and surface runoff that originates as precipitation eventually moves downwards through the unsaturated zone to recharge the ground-water system.

Net-infiltration results (Hevesi and others, 2003) were modified to create a recharge input for the ground-water system that balanced system discharges, the transmissive properties of the less permeable rock units at the water table, and the variable depth to the water table. Average annual netinfiltration was estimated with simulated net-infiltration from 1950 to 1999 (Hevesi and others, 2003). Based on the average annual net-infiltration rate and the relative permeability of rocks in the upper five flow model layers of the DVRFS model, a recharge input for the DVRFS model was created using nine zones and five recharge parameters. The nine zones were created by calculating the recharge rate and the relative permeability of rocks in the upper five flow model layers. In order to fit the recharge input to the observed discharge, recharge was adjusted using a recharge multiplication array and recharge parameters based on the nine zones (Faunt and others, 2004b, fig. F-35, p. 325 and table F-16, p. 326). The values of the five calibrated recharge parameters produced a total volume of recharge to the ground-water system that is not significantly different from the total volume of net-infiltration; for the entire model domain, 92 percent of the estimated netinfiltration was simulated as recharge.

\section{Multi-Node Well (MNW1) Package}

Simulation of pumpage from wells with the Well (WEL1) Package (McDonald and Harbaugh, 1988) is limited to withdrawal at specified rates from individual cells. However, the Multi-Node Well (MNW1) Package (Halford and Hanson, 2002) simulates pumpage from wells with screens that span multiple layers, partially penetrating wells, and variations in intraborehole flow. In the DVRFS region, wells typically are completed with screens that span multiple aquifers and thus multiple layers in the flow model. The vast majority of pumping occurs from model layers 1 through 4 (Faunt and others, 2004b, fig. F-8, p. 278). The MNW1 Package uses hydraulic conductivity and thickness to portion well pumpage between model layers. The DVRFS water budget (Faunt and others, 2004b, table F-18, p. 331) includes a small component of simulated well pumpage inflows due to simulated irrigation-return flows and well injection. A minor contribution of the simulated inflows is from intraborehole flow between pumping nodes connecting model layers within a single well in the MNW1 Package. 
Return flows were simulated because some return flow of pumpage by infiltration of excess irrigation, lawn water, or septic tank wastewater was anticipated. The magnitude and timing of return flow depends on the method (domestic, irrigation, or mining, public supply, and commercial) by which water is returned to the flow system (San Juan and others, 2004, p. 114-115). At each withdrawal point, return flow was estimated to be 20 percent of the estimated annual pumpage (Moreo and others, 2003) lagged by 7 years. All computed return flows were assumed to return to the water table at the location of the pumped well.

\section{Drain (DRN) Package}

The Drain Package, specified as file type "DRN", removes water from an aquifer through a head-dependent boundary (McDonald and Harbaugh, 1988). For a finitedifference cell specified as a drain cell, ground water is simulated as discharging when the simulated head in the cell rises above a specified drain altitude. When the head declines below the cell altitude, the drain is turned off. Simulated drain discharge is calculated as the drain conductance multiplied by the difference in altitude between the simulated head and the drain.

In the DVRFS model, evapotranspiration was simulated with the drain package for numerical stability. The altitude of the drain cells approximates the extinction depth for evapotranspiration (Faunt and others, 2004b, p. 271-278). Drain altitudes were set equal to $10 \mathrm{~m}$ below the lowest land-surface altitudes for each group of cells where natural discharge is observed (Faunt and others, 2004b, fig. F-7, p. 275 and table F-4, p. 276-277). Areas of natural discharge include wet playas, wetlands with free-standing water or surface flow, narrow drainages lined with riparian vegetation, and broad areas of phreatophytic shrubs and grass. For drain cells representing springs, the drain at that location is connected to the topmost occurrence of the lower carbonaterock aquifer, located between model layers 1 and 10.

Data for flows emanating from springs and seeps were derived from spring-flow measurements (San Juan and others, 2004, p. 103-110). Evapotranspiration rates were measured at Ash Meadows, Death Valley, and Oasis Valley as a proxy for discharge because most ground water discharging from springs and seeps is evaporated or transpired locally and is accounted for in estimates of evapotranspiration. Discharge simulated through the drain cells is compared to measured values in the section, "Observation (OBS) Process."

\section{Constant-Head Boundary (CHD) Package}

At cells defined as constant head, MODFLOW-2000 calculates flow into and out of the cell as needed to maintain the head. In the DVRFS model, lateral boundary flows are represented using the Constant-Head Boundary Package, specified as file type "CHD". CHD cells were specified in boundary cells that are at or below the regional potentiometric surface (Bedinger and Harrill, 2004a, 2004b) to allow flow across the boundary (Harrill and Bedinger, 2004). In the DVRFS model, the model boundary is not affected by simulated pumpage, and heads in the constant-head boundary cells do not change over time (Faunt and others, 2004b, table F-2, p. 270). Flows simulated through the constant-head boundaries are compared against reasonable estimates of flow in the section, "Observation (OBS) Process."

\section{Solver Packages}

Solver Packages, part of the GWF Process, are used to arrive at the solution of the finite-difference equations at each time-step in a stress period. Many different solvers have been written for MODFLOW (Hill, 1990; Harbaugh, 1995; Harbaugh and others, 2000). The DVRFS model is archived with the Preconditioned Conjugate-Gradient (PCG2) (Hill, 1990) solver, specified with file type "PCG2". Two additional solvers, Link to Algebraic Multigrid (LMG) solver (Mehl and Hill, 2001) and the Geometric Multigrid (GMG) solver (Wilson and Naff, 2004), both recently developed, typically are 2 to 25 times faster than the PCG (Wilson and Naff, 2004) solver. When used with the DVRFS model, the LMG solver was faster than the GMG solver for steady-state simulations but slower for transient simulations. Due to licensing restrictions, the distribution of the LMG solver is limited (URL: http://water.usgs.gov/nrp/gwsoftware/modflow2000/ modflow2000.html, accessed December 22, 2005). For steadystate simulations, the GMG solver is often much faster than the PCG2 solver. 


\section{Observation (OBS) Process}

The OBS Process generates simulated (or modelcalculated) values for comparison with measured, or observed, values. Additionally, observation sensitivities are calculated for use in sensitivity analysis and for regression during parameter calibration (Hill and others, 2000). By defining an observation value and a weight associated with the observation, either as a standard deviation or a coefficient of variation (standard deviation divided by the mean), observed values can be compared to simulated values to evaluate model fit in the context of expected observation accuracy. Statistics calculated to quantify this comparison include a weighted least-squares objective function (Hill, 1998). In addition, when the OBS Process is active, output files are produced for comparison of simulated and observed values (Hill and others, 2000, p. 23).

The OBS Process requires an input file identified by file type "OBS". The tasks of the Observation Process are as follows:

1. Read a file (file type OBS) that contains information applicable to all observations.

2. Read observed values and information needed to calculate associated simulated values. This information is provided through input files related to the active GWF Processes. For example, if an observed flow is represented using the Constant-Head Boundary (CHD) Package, an Observation Process Constant-Head Boundary Package (specified as file type $\mathrm{CHOB}$ ) input file is needed.

3. Calculate associated simulated equivalents to the observations using hydraulic heads for the entire grid.

4. If the SEN Process is active, calculate the associated observation sensitivities using the grid sensitivities calculated by the SEN Process.

5. Calculate statistical measures and output files for simulated and observed values (Hill, 1998, table 1, p. 33).

Observation inputs for the DVFRS model include: (1) head observation file (specified as file type HOB) for hydraulic heads and changes in hydraulic head over time, (2) drain observation file (specified as file type DROB) for natural flows to or from surface-water bodies and diffuse discharge areas represented with the DRN Package, and (3) flow observations at constant-head boundaries file (specified as file type CHOB) for flow to or from a set of constant-head finitedifference cells along parts of the model boundary as specified in the CHD Package.

\section{Head Observation (HOB) Package}

Hydraulic head or head change observations are specified in the Head Observation Package, specified as file type "HOB". For each observation, the head observation and observation weight are defined by layer(s), row, column, and time of the observation. Head observations are located as a row and column offset from the node at the center of the finite-difference cell (Hill and others, 2000, p. 31-40). In the DVRFS model, head observations for wells with water-level measurements over multiple years were determined to be either affected or not affected by pumping. Head observations affected by pumping were simulated as a head change, which is calculated as the difference between the observation of interest and a reference observation (Hill and others, 2000, p. 33-34). The reference observation is the measurement prior to any pumping effect or the first measurement available.

The open intervals of the wells and boreholes determined which model layers were associated with head and headchange observations. Most head and head-change observations (82 percent) are from wells completed in the shallow part of the flow system (no deeper than model layer 5) and none are deeper than model layer 14 (Faunt and others, 2004b, fig. F-8, p. 278). For wells open to more than one model layer, simulated heads are a weighted average calculated by MODFLOW-2000 with user-defined weights (Hill and others, 2000, p. 34-36). In the DVRFS model, the standard deviation of a head observation is based on five potential errors: (1) well-altitude error, (2) well-location error, (3) nonsimulated transient error, (4) measurement-accuracy error, and (5) model-discretization error (San Juan and others, p. 122-132). Well-altitude and well-locations errors vary with the type of instrument or method used to specify the well location. Nonsimulated transient errors result from uncertainty in the magnitude of water-level response caused by stresses not simulated in the flow model, which typically are seasonal and long-term climate changes. A separate method was used to calculate the standard deviation of head-change observations because differences between simulated and observed head changes are expected to be dominated by inaccurate pumpage estimates (Faunt and others, 2004b, p. 282). Standard deviations for head-change observations less than $1 \mathrm{~m}$ were assigned a value of $1 \mathrm{~m}$ to avoid very small errors that could cause numerical instability during calibration. For head change observations greater than $1 \mathrm{~m}$, a function was developed that produced larger standard deviations for larger head differences but also tempered the range in standard deviation between large and small head-change observations (Faunt and others, 2004b, p. 282, eq. 4). 


\section{Drain Observation (DROB) Package}

Drain observations in the Drain Observation Package are specified as file type "DROB". At each finite-difference cell specified as a drain cell, discharge observations, observation weight, and time of observation are defined.

In the DVRFS model, ground-water discharge observations did not vary during the transient simulation with the exception of Manse and Bennetts Springs in Pahrump Valley (fig. 1). At this location, changes in discharge have been documented during the model simulation period (fig. 3). For each of these springs, a single observation occurs during the steady-state stress period, and two transient discharge observations occur during the stress periods representing 1960 and 1998. For all other 43 ground-water discharge locations in the DROB Package, observations only occur once during the stress period representing 1997 (San Juan and others, 2004, p. 103-110).

In the DVRFS model, the weight of a ground-water discharge observation is represented as a coefficient of variation based on Monte Carlo analysis (Laczniak and others, 2001; D'Agnese and others, 2002; Faunt and others, 2004b, p. 283). The coefficients of variation for discharge observations range from 0.10 to 0.71 (Faunt and others, 2004b, table F-4, p. 276-277).

\section{Constant-Head Flow Observation (CHOB) Package}

At finite-difference cells defined as constant head cells, the model calculates the flow into and out of cells needed to maintain the head. If anything is known about the likely flow rate, it is important to include it to constrain model calibration (Poeter and Hill, 1997). These flows are input through the Constant-Head Flow Observation Package, specified as file type "CHOB".

In the DVRFS model, locations of the constant-head flow observations coincide with the locations of the 12 constant-head boundary parameters that represent segments of the model boundary. These 12 segments potentially have flow across them based on water budget analyses (Harrill and Bedinger, 2004) (fig. 2). Harrill and Bedinger (2004) estimated the potential for flow through boundary segments of the DVRFS model domain (table A2-9, p. 406-407).

Constant-head flow observations are specified only during the first stress period. Observation weights are calculated from specified standard deviations that were based on the method used to estimate flow at the boundary (Harrill and Bedinger, 2004). For boundary-flow estimates based on water-budget analyses (Harrill and Bedinger, 2004), the standard deviation was set to one-half of the estimated flow value which reflects

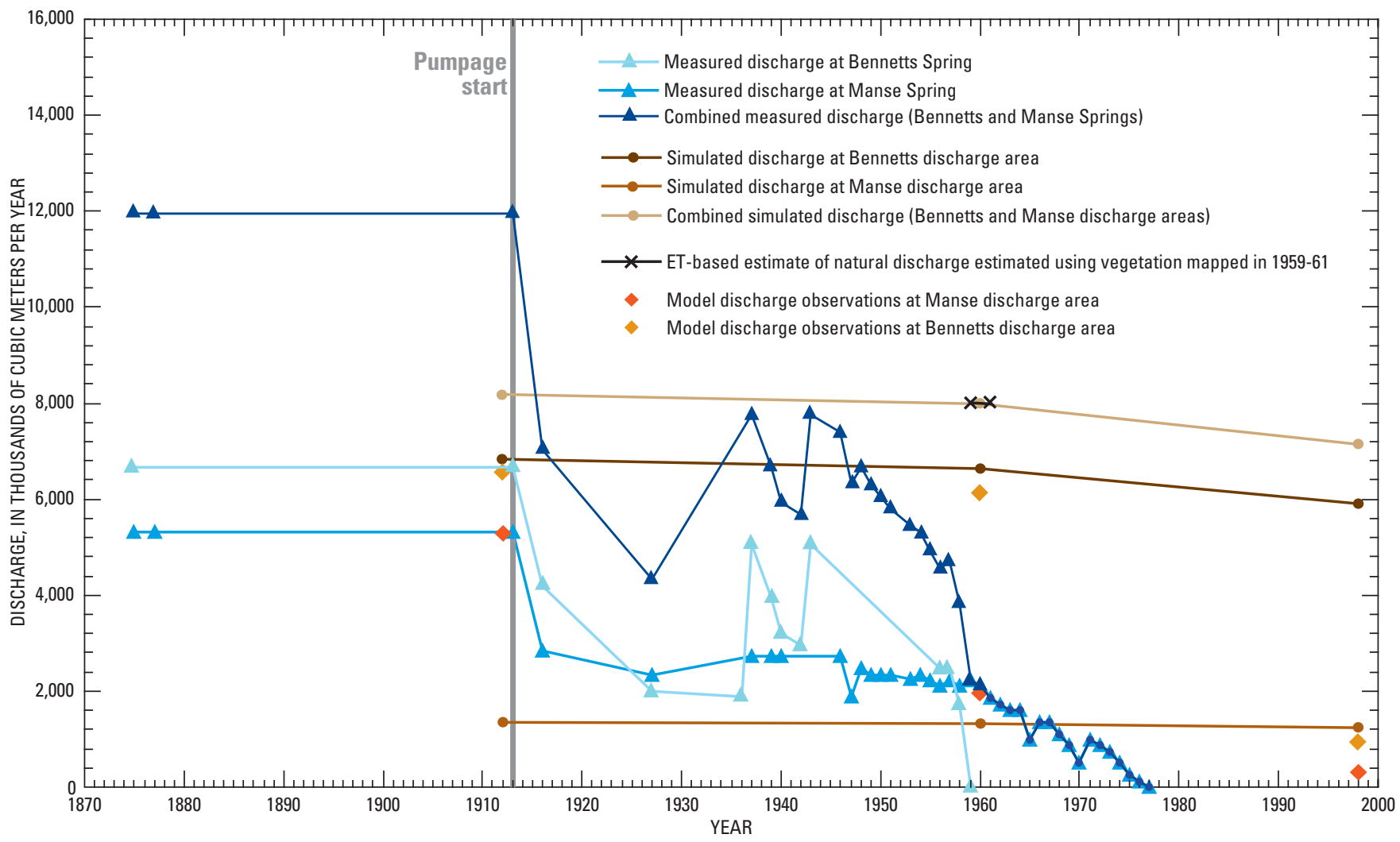

Figure 3. Annual discharge from Bennetts and Manse springs in Pahrump Valley, Nevada, 1875-1998. 
the large uncertainty in these values. In eight of the segments, water budget analyses were not available, so Darcy's law (with the regional potential gradient) and professional judgment were used to estimate flow across the boundary (Harrill and Bedinger, 2004). In these poorly constrained cases, the standard deviation was set to the estimated flow value rounded down to the nearest $500 \mathrm{~m}^{3} / \mathrm{d}$. For poorly constrained boundary-flow estimates, the large standard deviation reflects the large uncertainty.

\section{Sensitivity (SEN) Process}

The Sensitivity Process (Hill and others, 2000), specified as file type "SEN", calculates the sensitivity of hydraulic heads with respect to parameters. These sensitivities are grid sensitivities. If the OBS Process is active, grid sensitivities are used to calculate sensitivities for the simulated values associated with the observations with respect to a parameter. These sensitivities are called observation sensitivities. Observation sensitivities are used to calculate a number of statistics that can be utilized to: (1) diagnose inadequate data, (2) identify parameters that probably cannot be estimated by regression using the available observations, and (3) evaluate potential new data (Hill and others, 2000). Model output for the sensitivity process includes: (1) composite scaled sensitivities, (2) dimensionless scaled sensitivities, and (3) one-percent scaled sensitivities (Hill, 1998, p. 14-16). Flags in the first data row of the SEN Process, in combination with processes specified in the name file, control whether the SEN Process or PES Process (described in section, "Sensitivity (SEN) Process") are active in MODFLOW-2000.

In the DVRFS model, parameter values specified in the SEN Process are used to calculate the horizontal-flow barrier characteristic $[(\mathrm{m} / \mathrm{d}) / \mathrm{m}]$, drain conductance $[(\mathrm{m} / \mathrm{d}) / \mathrm{m}]$, hydraulic conductivity $(\mathrm{m} / \mathrm{d})$, recharge multiplier (unitless), exponential depth decay coefficient $(1 / \mathrm{m})$, specific storage $(1 / \mathrm{m})$, and vertical anisotropy (ratio of horizontal to vertical hydraulic conductivity) (unitless) (table 3). All parameters, with the exception of the specific storage parameters, were log-transformed during parameter estimation.

In the DVRFS model, the SEN Process specifies the value of all model parameters with the exception of the simulated heads at constant-head boundaries. The SEN Process provides one location to change all parameter values. Because the simulated lateral boundary flows were not calibration targets, constant-head boundary parameters are defined in the CHD and CHOB Packages but are not included in the SEN Process (effectively a parameter value of 1).
Generally, in the DVRFS model, the value of a parameter in the SEN Process is multiplied by additional values (termed factors) in other package(s) to obtain the cell-by-cell model input used in MODFLOW-2000 calculations. For example, in the HFB6 Package, the parameter value in the SEN Process is multiplied by a factor of 1 (table 4). A HFB6 parameter is defined as the hydraulic characteristic, which is the flow barrier hydraulic conductivity divided by the flow barrier width. At cells specified as HFB6 cells, the Factor variable is used to calculate the hydraulic characteristic of the flow barrier as the product of Factor and the parameter value. All hydraulic barriers in the DVRFS model were represented as $1 \mathrm{~m}$ wide (Faunt and others, 2004b, p. 269). Consequently, the hydraulic characteristic and the hydraulic conductivity are numerically equivalent, and for all cells specified as HFB6 cells, the value of Factor is 1.

In other cases, such as the DRN Package, the value of the drain parameter in the SEN Process is multiplied by a factor other than 1 at each grid cell. In the DRN Package, the multiplicative factor represents the fractional area of the cell that contributes to natural discharge, evapotranspiration and/or spring flow (table 4). It is convenient to represent parameters in the DRN Package with a factor other than 1 because drain parameters define a conductance that depends on the area of the cell contributing discharge. This area dependence is represented by the value of the multiplicative factor at each drain cell. For each cell specified as a drain cell, the variable "Condfact", the factor used to calculate the hydraulic conductance of the drain from the parameter value, is the fractional area of the cell that the drain occupies.

In the DVRFS model, recharge is specified by values in the MULT and ZONE files, the RCH Package, and SEN Process. The distributed net infiltration array (Hevesi and others, 2003) input for the DVRFS model is the multiplier array rch1_modmd.asc. For each of the five parameters in the $\mathrm{RCH}$ Package, the parameter value, which varies by zone, is multiplied by values in the multiplier array.

Model input for parameter types not listed in table 4 include hydraulic conductivity (HUF2 Package parameter type HK), KDEP, vertical anisotropy (parameter type VANI), and specific storage (parameter type SY and SYTP). For these parameter types, cell-by-cell model values are calculated with the multiplier and zone arrays listed in the HUF2 Package and parameter values specified in the SEN Process (Anderman and Hill, 2000, 2003). 
Table 3. Description of the parameter names in the sensitivity file and the associated packages and files.

[Package/File associated with parameter: DRN, Drain Package; HFB6, Horizontal-Flow Barrier Package; HUF2, Hydrogeologic-Unit Flow Package; KDEP, Hydraulic-conductivity depth-dependence parameter; RCH, Recharge Package; SEN, Sensitivity Process. Abbreviations: m/d, meter per day; (m/d)/m, meter per day per meter; $1 / \mathrm{m}, 1$ over meter]

\begin{tabular}{|c|c|c|c|}
\hline Parameter name description (units) & $\begin{array}{c}\text { Package/file } \\
\text { associated with } \\
\text { parameter }\end{array}$ & $\begin{array}{l}\text { Number of parameters } \\
\text { defined in the } \\
\text { SEN process }\end{array}$ & $\begin{array}{l}\text { Parameter name } \\
\text { prefix or suffix }\end{array}$ \\
\hline Fault hydraulic characteristic $[(\mathrm{m} / \mathrm{d}) / \mathrm{m}]$ & HFB6 & 9 & $\mathrm{~B}_{-}$ \\
\hline Drain conductance $[(\mathrm{m} / \mathrm{d}) / \mathrm{m}]$ & DRN & 7 & $\mathrm{DRN}^{1}$ \\
\hline Hydraulic conductivity of confining units $(\mathrm{m} / \mathrm{d})$ & HUF2 & 8 & $\mathrm{~K} 1$ \\
\hline Hydraulic conductivity of carbonate-rock aquifers $(\mathrm{m} / \mathrm{d})$ & HUF2 & 20 & $\mathrm{~K} 2$ \\
\hline Hydraulic conductivity of volcanic-rock units (m/d) & HUF2 & 14 & K3 \\
\hline Hydraulic conductivity of basin-fill units (m/d) & HUF2 & 14 & K4 \\
\hline Exponential depth decay coefficient $(1 / \mathrm{m})$ & HUF2, KDEP & 10 & KDEP or KDP \\
\hline Recharge multiplier (unitless) & $\mathrm{RCH}$ & 5 & $\mathrm{RCH}_{-}$ \\
\hline Specific yield value applied to top model layer (unitless) & HUF2 & 3 & $\mathrm{SY}_{-}$ \\
\hline Specific storage $(1 / \mathrm{m})$ & HUF2 & 4 & STOR_ \\
\hline Vertical anisotropy (unitless) & HUF2 & 6 & VANI or VAN ${ }^{1}$ \\
\hline
\end{tabular}

${ }^{1}$ Suffix appears at the end of the parameter name in the SEN file.

Table 4. Sensitivity Process and associated factors for Constant-Head Boundary, Drain, Horizontal-Flow Barrier, and Recharge Packages.

[Abbreviations: CHD, Constant-Head Boundary Package; DRN, Drain Package; HFB6, Horizontal-Flow Barrier Package; RCH, Recharge Package; SEN, Sensitivity Process; MULT, multiplier file. NA, not applicable. m/d, meter per day; (m/d)/m, meter per day per meter; m, meter]

\begin{tabular}{|c|c|c|c|c|}
\hline Package & Parameter Type & Factor variable & $\begin{array}{l}\text { Units of the parameter value } \\
\text { in the SEN Process }\end{array}$ & Comment \\
\hline $\mathrm{CHD}$ & Hydraulic head (m) & Shdfact $^{1}=$ Ehdfact $^{2}$ & $\mathrm{NA}^{3}$ & $\begin{array}{l}\text { Head is the product of Ehdfact }{ }^{2} \text { and the parameter } \\
\text { value in the SEN Process. }\end{array}$ \\
\hline DRN & Drain conductance $[(\mathrm{m} / \mathrm{d}) / \mathrm{m}]$ & Condfact ${ }^{4}$ & Hydraulic conductance $[(\mathrm{m} / \mathrm{d}) / \mathrm{m}]$ & $\begin{array}{l}\text { Drain hydraulic conductance }{ }^{5} \text { is the product of } \\
\text { Condfact and the parameter value in the SEN } \\
\text { Process. }\end{array}$ \\
\hline $\mathrm{RCH}$ & Recharge flux (m/d) & NA & Unitless multiplier & $\begin{array}{l}\text { Parameter value in the SEN Process is multiplied } \\
\text { by the multiplier array }{ }^{6} \text { value at each cell. }\end{array}$ \\
\hline
\end{tabular}

\footnotetext{
${ }^{1}$ Shdfact is the factor used to calculate the head at the boundary at the start of the stress period.

${ }^{2}$ Ehdfact is the factor used to calculate the head at the boundary at the end of the stress period.

${ }^{3}$ No CHD parameters are defined in the SEN Process. CHD parameters are defined only in the CHD Package. This is effectively a parameter value of 1.0.

${ }^{4}$ In the DVRFS model, the value of Condfact is the fractional area of a cell that the drain parameter occupies.

${ }^{5}$ Hydraulic characteristic is the barrier hydraulic conductivity divided by the width of the barrier. In the DVRFS model, the width of all barriers is assumed to be 1.0 meter; consequently, the hydraulic characteristic and the hydraulic conductivity are numerically equivalent.

${ }^{6}$ The multiplier array file is rch1_modmd.asc as specified in the MULT file (mult.txt).
} 


\section{Parameter-Estimation (PES) Process}

The Parameter-Estimation Process (Hill and others, 2000), specified as file type "PES", uses a modified GaussNewton method to adjust values of user-selected input parameters to minimize the value of the weighted least-squares objective function via iteration. The objective function, the sum of squared weighted residuals, is used to evaluate the fit of simulated to observed values. Residuals are the difference between simulated and observed model values (observed minus simulated). Weighted residuals in the DVRFS model most often reflect a weight equal to the inverse of the standard deviation of the observation squared. Thus, squared weighted residuals for all types of observations can be summed as dimensionless quantities.

Parameter estimation is initiated using parameter values from the SEN Process. Hydraulic heads and sensitivities are calculated for each time step. After all time steps are computed, simulated values are subtracted from observed values to calculate residuals, which are used to compute the least-squares objective function. Convergence criteria specified in the PES Process include maximum allowable values of: (1) the largest fractional change in any of the parameter values, and (2) the change in the weighted leastsquares objective function. If either of the two convergence criteria is met, parameter estimation converges. If parameter estimation does not converge and the maximum number of iterations has not been exceeded, updated parameter values are used in subsequent parameter-estimation iterations. When parameter estimation converges or the maximum number of iterations is reached, the PES Process halts.

\section{Model Output}

For DVRFS model simulations, MODFLOW-2000 generates two listing output files (as specified in the name file). Most of the output from the GWF and SEN Processes is written to the LIST file, while output that applies to the overall model simulation is written to the GLOBAL file. The LIST file includes allocation information, values used by the GWF Process for layers and individual cells to solve the flow equation, and calculated model results such as hydraulic head, drawdown, and the water budget. When the OBS Process is active, the LIST file also contains the model-calculated equivalents to the observations and the related statistics. When the PES Process is active and a new iteration begins, the LIST file is erased and regenerated. As a result, most of the GWF and SEN Process output is limited to that produced during the most recently executed parameter-estimation iteration.
The GLOBAL file contains information that applies to the model simulation as a whole. This output includes the names and types of all input files. Input for the GLO Process is echoed in the GLOBAL file. The GLOBAL file includes spatial and temporal discretization, and solver information. The GLOBAL file also contains parameter definitions read from the various packages that define boundary conditions and stresses for the GWF Process. Input from active OBS, SEN, and PES Processes is echoed to the GLOBAL file. If the OBS, SEN, and PES Processes are all active, the GLOBAL output file contains:

1. Information about the array storage needed by the OBS, SEN, and PES Processes.

2. Information about the definition of parameters and observations.

3. Observation-sensitivity tables produced using the starting parameter values. Observation sensitivities include dimensionless scaled sensitivities and composite scaled sensitivities, and (or) one-percent scaled sensitivities.

4. Parameter values and other information from each parameter-estimation iteration.

5. Observation sensitivity tables produced using the final parameter values.

6. Parameter variance-covariance and correlation matrices.

7. Parameter confidence intervals.

8. A comparison of the parameter values and userdefined reasonable upper and lower limits of the parameter value.

9. Summary statistics about the model fit to the observations.

The LIST output file contains:

1. Information about the array storage needed by each GWF Process Package.

2. Printed arrays of heads for the entire model grid. The printed arrays depend on the contents of the GWF Process, BAS6 Package, and OC Option.

3. Tables that list observed and simulated values from the latest set of parameter values.

4. Observation-sensitivity tables calculated using the most recently calculated grid sensitivities. Possibilities include dimensionless scaled sensitivities, composite scaled sensitivities, and (or) one-percent scaled sensitivities. 
Table 5. Select output files produced by MODFLOW-2000 by active processes.

[Modified from Hill and others, 2000, p. 28. File contents: Observation process: For each observation, the listed items are followed by the variables OBSNAM and PLOT-SYMBOL. File contents: Parameter estimation outputs from MODFLOW-2000, which are inputs for post-processing programs RESAN-2000, BEALE-2000, and YCINT-2000 (Hill and others, 2000) are not included in this table. Abbreviation: SEN, Sensitivity Process]

\begin{tabular}{cl}
\hline \multicolumn{1}{c}{ Extension } & \multicolumn{1}{c}{ File contents } \\
\hline If the Observation Process is active: \\
_nm & Weighted residuals and probability plotting positions \\
_os & Unweighted simulated equivalents and observations \\
_r & Unweighted residuals \\
_W & Weighted residuals \\
_ww & Weighted simulated equivalents and observations \\
_ws & Weighted simulated equivalents and residuals \\
If the Sensitivity Process also is active, the following files also are \\
produced: \\
_sc \\
Composite scaled sensitivity for each parameter, \\
pd \\
preceded by the PARNAM.
\end{tabular}

${ }^{1}$ PARNAM is a parameter name that is specified in a Ground-Water Flow Process package and the SEN Process.

${ }^{2}$ OBSNAM are characters used to identify an observation.

${ }^{3}$ PLOT-SYMBOL is an integer assigned to each observation in an observation input file that is echoed to many output files.

${ }^{4}$ The Marquardt parameter is used to improve regression for ill-posed problems (Hill, 1998, p. 8-9).
Additional output files are produced by the OBS Process (table 5). These files are designed for use by plotting routines and other programs (Harbaugh, 1990; Hanson and Leake, 1999; Winston, 2000). Output files are named using a file name base, defined by the user in the OBS Process variable OUTNAM. Files are named as OUTNAM followed by a period and an extension that begins with an underscore. For example, if OUTNAM is "dvr", the output file names are "dvr._os" and so on. These files are collectively referred to as the "underscore" output files.

In all "underscore" output files (dvr._* files) produced when the OBS Process is active (table 5), the plot symbol variable (PLOT-SYMBOL) is used to identify an observation as either a head observation (PLOT-SYMBOL is 0 or 1 ), a head-change observation (PLOT-SYMBOL is 2, 3, or 4), a discharge observation (PLOT-SYMBOL is 3), or a constanthead flow observation (PLOT-SYMBOL is 3) (table 6). Although the PLOT-SYMBOL value of 3 is used for head change, discharge, and constant head flow observations, the observation type can be easily identified from the observation name (variable OBSNAM). Numeric OBSNAMs indicate head change observations; alphabetic OBSNAMs indicate constanthead boundary flows and discharge observations. Furthermore, for constant-head flow observations, the OBSNAM begins with "C_". For discharge observations, the OBSNAM begins with "OBS" for steady-state observations, "OB" for observations in the stress period representing 1960, and "O" for observations in the stress period representing 1998.

Table 6. Plot symbol codes that identify the observation type in all "underscore" output files created during forward and parameter-sensitivity mode simulations.

[Abbreviations: m, meter; Symbol: $\geq$, greater than or equal to; $\leq$, less than or equal to; >, greater than; =, equal to]

\begin{tabular}{cc}
\hline Plot symbol & Description \\
\hline 0 & $\begin{array}{c}\text { Head observation derived from few steady-state } \\
\text { measurements. }\end{array}$ \\
1 & $\begin{array}{c}\text { Head observation derived from many steady-state } \\
\text { measurements. }\end{array}$ \\
2 & $\begin{array}{c}\text { Head change observation } \geq 0.1 \mathrm{~m} \text { and } \leq 1 \mathrm{~m} \text {, standard } \\
\text { deviation }=1 \mathrm{~m} \text {. }\end{array}$ \\
& $\begin{array}{c}\text { Head change observation }<0.1 \mathrm{~m} \text {, standard deviation } \\
=1 \text { m, or discharge observation, or constant head } \\
\text { observation. }\end{array}$ \\
& $\begin{array}{c}\text { Head change observation }>1 \mathrm{~m}, \text { standard deviation is } \\
\text { a function of head change observation. }\end{array}$ \\
\end{tabular}




\section{Typical DVRFS MODFLOW-2000 Modes}

The source code used in the DVRFS model (mf2k_13_00-dp.exe) is MODFLOW-2000 version 1.13 compiled to run in double precision. A model simulation is conducted by executing "mf2k_13_00-dp.exe" in a DOS window and entering "name. txt" when prompted for the name file. The source code is available from the USGS website at URL: http://pubs.water.usgs. gov/sir20045205/, accessed on December 22, 2005, under model archive. Single precision simulations result in inaccurate water budgets due to rounding errors. The most recent version of MODFLOW-2000, version 1.15.01, is available at URL: http://water. usgs.gov/nrp/gwsoftware/modflow2000/modflow2000.html, accessed on December 22, 2005. The executable file available at the website is single precision, and the source code must be recompiled in double precision.

Various simulation modes are available in MODFLOW-2000 depending on the file types activated in the name file, and the values assigned to variables in the SEN and PES Processes. In general, four types of model modes are thought to be most relevant to simulations with the DVRFS model: (1) forward with observations and parameter-value substitution, (2) parameter sensitivity with observations, (3) sensitivity-analysis, and (4) the parameter-estimation mode (table 7) (Hill and others, 2000, p. 12). The two parameter-sensitivity modes (modes 2 and 3) produce similar output files; however, depending on the parametersensitivity mode, different statistics are written to the GLOBAL file (table 6).

For discussion, it is assumed that the OBS Process is always active, and parameter-value substitution (values from the SEN Process are always used) occurs. In all modes, a LIST file and a GLOBAL file are created. However, different information is written to these two files depending on the mode and which processes (OBS, SEN, PES) are active (table 6).

\section{Forward Mode}

Forward mode generally is the simplest mode and also is the mode most similar to MODFLOW-96. To execute a simulation in forward mode with observations and parameter-value substitution (Hill and others, 2000, p. 12), include the SEN and PES Process file types in the name file (for example, see the archived model name file). In the SEN Process (SENSITIVITY.txt), set the second variable (first data row, second column entry variable INSENALL) to -1 . Shown below are the first few lines of the SEN Process with the ISENALL variable shaded in gray:

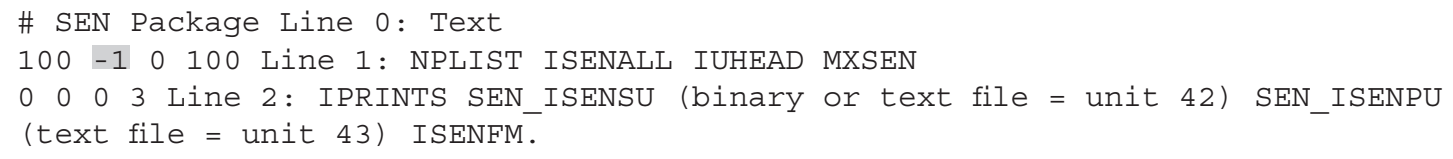

The forward mode with observations and parameter value substitution can generate head and drawdown arrays for contouring, water-budget terms, and the fit of simulated equivalents to observations. Model time steps for which output is saved and printed are determined by the OC Option. In the DVRFS model, arrays of simulated head and drawdown by layer and time, as specified in the OC Option, are contained in the files HEADSOUT.TXT and DRAWDOWN.TXT, respectively. The HEADSOUT.txt and DRAWDOWN.txt files are specified as the file type "DATA" in the name file.

Output files created in the forward mode with observations and parameter value substitution include GLOBAL, LIST, HEADSOUT.txt, DRAWDOUT.txt and the "underscore" output files (dvr._* files) are listed in table 5. 
Table 7. Modes of MODFLOW-2000 produced by activating different combinations of the Sensitivity and Parameter-Estimation Processes, and commonly used output when the Observation Process is active.

[Modified from Hill and others, 2000, p. 12. Abbreviations: OBS, Observation Process; PES, Parameter-Estimation Process; SEN, Sensitivity Process]

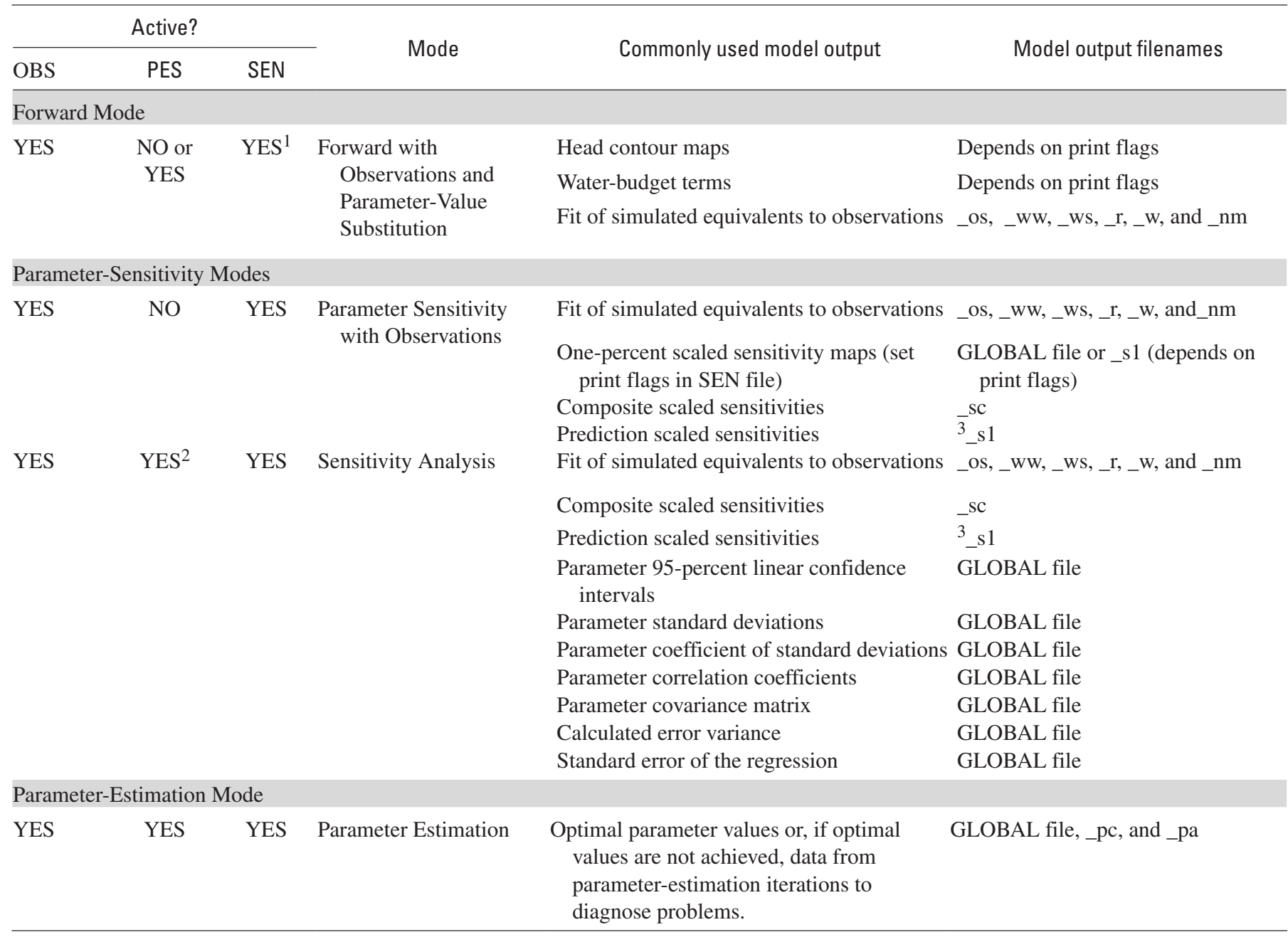

\footnotetext{
${ }^{1}$ ISNEALL $<0$ in the Sensitivity Process input file.
}

${ }^{2} \mathrm{MAX}-\mathrm{ITER}=0$ in the Parameter-Estimation Process input file.

${ }^{3}$ One-percent scaled sensitivities in this file are often used as prediction scaled sensitivities. Predictions scaled sensitivities can be calculated from one-percent scaled sensitivities (Hill, 1998, p. 15-17). 


\section{Parameter-Sensitivity Modes}

To execute a model simulation in a parameter-sensitivity mode, activate the SEN Process and inactivate the PES Process in the name file (parameter sensitivity with observations mode), or make the PES Process active with the variable MAX-ITER set to zero (sensitivity-analysis mode). To calculate sensitivities for all parameters, activate the parameter sensitivity with observations mode by setting the second variable (ISENALL) in the first data row of the SEN Process to 1 . The first few lines of the SEN Process are shown below with the ISENALL variable shaded in gray:

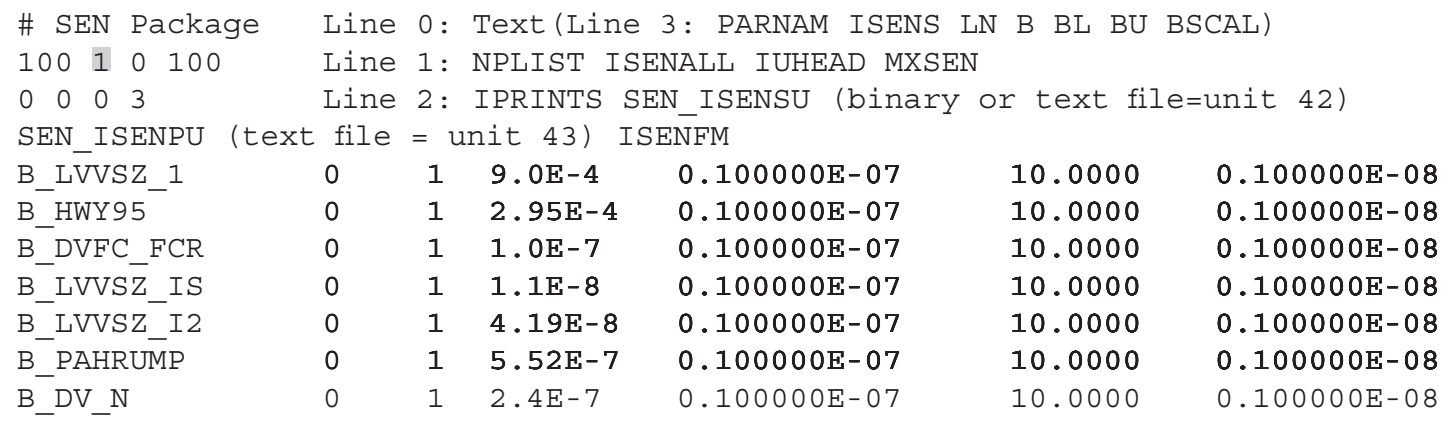

Calculating sensitivities for individual parameters, or a subset of parameters, is much faster than calculating sensitivities for all parameters. If only a part of the DVRFS modeling area is of interest to a user, sensitivities can be calculated only for parameters in the subarea of interest. To calculate sensitivities for only select parameters, set the second variable (INSENALL) in the first data row of the SEN Process to 0 . Next, for each parameter for which sensitivity output is desired, set the second column (variable ISENS) to 1. Shown below are the first few lines of the SEN Process with the ISENALL variable shaded in gray. As designated by the Boolean flag in the second column (variable ISENS), sensitivities will only be calculated for the fault conductance parameters B_HWY95 and B_DV_N:

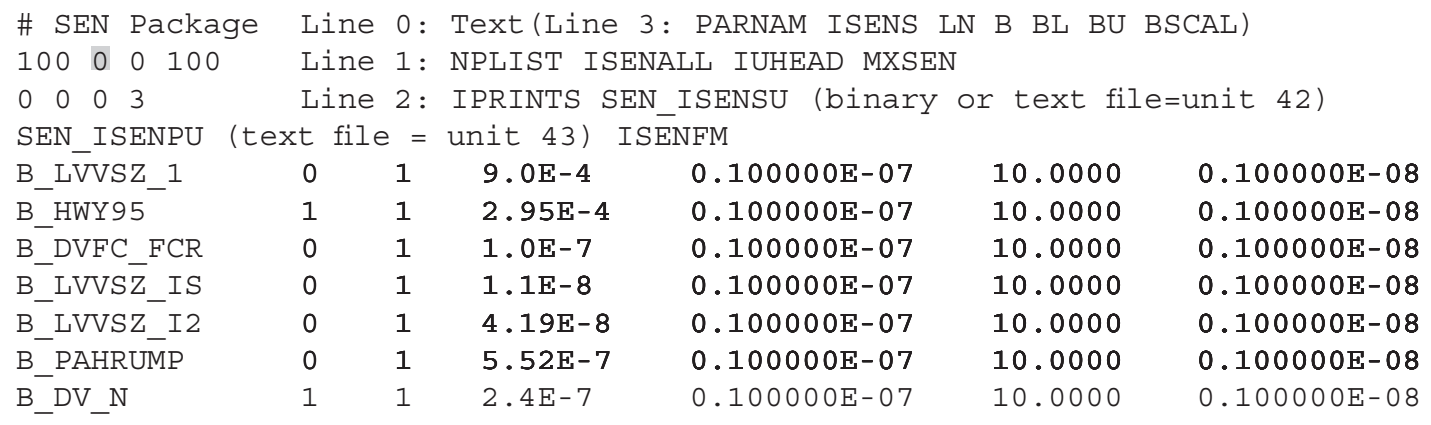

In addition to all the output created in the forward mode, additional output files (dvr._sc, dvr._sd, and dvr._s1) are produced when the SEN Process is active (table 7). These output files list composite scaled sensitivities (dvr._sc) and dimensionless scaled sensitivities (dvr._sd) for each selected parameter, and prediction scaled sensitivities (dvr._s1) for each observation for each selected parameter. Statistics written to the GLOBAL file in the parameter-sensitivity mode that are not produced during a forward model simulation include the calculated error variance, the standard error of the regression, and parameter correlation coefficients (Hill, 1998). 


\section{Parameter-Estimation Mode}

To execute a model simulation in parameter-estimation mode, activate the SEN and PES Processes in the name file. In the PES Process, also set the variable MAX-ITER to 1. Parameter-sensitivity mode output includes one-percent scaled sensitivity arrays (set additional print flags in the SEN Process and OC Option), the fit of simulated equivalents to observations, composite scaled sensitivities, and prediction scaled sensitivities. Parameter-estimation mode will produce optimal parameter values for the observation weights if convergence is achieved. When the PES Process is activated in the name file, the method of running this mode for all parameters or for a set of parameters is the same as previously described for the parameter-sensitivity mode.

Output produced only in the parameter-estimation mode, including the dvr. pa and dvr._pc files, contains information about parameter estimation by iteration and only final parameter estimates, respectively. With an active PES Process, additional statistics, such as estimated parameter values, standard deviations, coefficients of variation, and 95 percent linear confidence intervals, are written to the GLOBAL file (table 7) (Hill, 1998).

\section{Typical Uses of the DVRFS Model}

Since publication of the DVRFS model, the authors have responded to model users regarding questions about predictive pumping scenarios and conversion of the model from a transient to a steady-state simulation. Both of these scenarios are addressed in following sections which pertains to editing the model archive files. The required editing of model inputs to achieve these model modifications for execution in forward model mode with observations and parameter-value substitution (Hill and others, 2000, p. 12) is described. The observation packages (CHOB, DROB, and HOB) are not required to conduct model simulations in forward mode when the OBS Process is inactive. However, conducting model simulations in the forward mode with the OBS Process active produces additional output that aids model evaluation. If a user is not utilizing the OBS Process, inactivate the OBS Process and the CHOB, DROB, and HOB Packages in the name file and disregard editing instructions for these files.

\section{Predictive Pumping Scenarios}

To simulate predictive pumping scenarios, or pumping that extends beyond the last stress period of the DVRFS model, the DIS file and the WEL1 Package (or the MNW1 Package) are the primary two files that require editing. The total length of the model simulation may be changed by adding additional stress periods in the DIS file. Any pumping that occurs during these additional stress periods can be included in the WEL1/MNW1 Package by specifying pumping rates, well locations, and time of pumping. All other packages which contain parameter information by stress period (CHD, HFB6, DRN, and RCH Packages) also need to reflect an increase in the total number of stress periods. Parameter definitions from the previous time step may be repeated for each of the new stress periods.

In the DIS file, extend the number of stress periods by adding a line, at the end of the file, for each additional stress period, and increase the total number of stress periods (variable NPER).

- For example, in the first data row of the DIS file (DIS_WT_CONFINED.txt), increase the total number of stress periods from 87 to 90 as indicated by the gray highlighting of the variable NPER:

\# DIS Package Line 0: Text

161941609042 Line 1: NLAY NROW NCOL NPER ITMUNI LENUNI

Next, specify the length of each of the three additional stress periods (variable PERLEN), the number of time steps (variable NSTP), the time step multiplier (variable TSMULT), and identify the additional stress period as transient (TR).

- For example, at the end of the DIS file, add three new transient stress periods, each 4 years in length with 3 time-steps and a time step multiplier of 1 , for a total of 90 stress periods:

\footnotetext{
146231 TR Line 7: PERLEN NSTP TSMULT (stress period 88)

146231 TR Line 7: PERLEN NSTP TSMULT (stress period 89)

146231 TR Line 7: PERLEN NSTP TSMULT (stress period 90).
} 
Well locations are identified by model layer, row, and column. Approximate well locations by row and column can be calculated from Universal Transverse Mercator (UTM) coordinates using the following equations:

$$
\begin{aligned}
& \text { Column }=\operatorname{INT}((\text { easting }-437,000) / 1500)+1 \\
& \text { Row }=\operatorname{INT}((4,219,000-\text { northing }) / 1500)+1
\end{aligned}
$$

where

INT is a function which converts a real number to an integer by truncating values after the decimal point, and the easting and northing coordinates are UTM zone 11.

To add additional pumping or well injection during the three new stress periods, add to the end of the WEL1 Package the number of non-parameter wells read for the current stress period (variable ITMP), and the layer, row, and column of the well followed by the pumping rate (variables Layer, Row, Column, and Q) for each stress period. A negative pumping rate indicates discharge from the ground-water system. For example, to add a pumping well (model layer 1, row 141, column 100) and another pumping well (model layer 1, row 147 and column 104) that each pump at a rate of $2.36 \mathrm{~m}^{3} / \mathrm{d}$ in each of the three additional stress periods, the following lines would be added to the end of the WEL1 Package:

$\begin{array}{lll}141 & 100 & -2.36 \\ 147 & 104 & -2.36 \\ 141 & 100 & -2.36 \\ 147 & 104 & -2.36 \\ & & \\ 141 & 100 & -2.36 \\ 147 & 104 & -2.36\end{array}$

After editing files, execute MODFLOW-2000 in the forward mode with observations and parameter-value substitution.

\section{Converting from a Transient to Steady-State Simulation}

For users who wish to compare DVFRS hydraulic properties with an existing model, it may be an advantage to run the model with steady-state conditions, instead of transient conditions, for faster sensitivity analysis computations. Oftentimes in ground-water modeling, a steady-state solution is approximated with a long transient stress period. Significant drawdown occurs at some locations in the DVRFS model and adding a long final transient stress period to the existing model would require rewetting if pumping was turned off during a long final stress period. As rewetting may result in numerical instabilities (Harbaugh and others, 2000), a different approach is proposed.

To convert the DVRFS model from a transient to a steady-state simulation, some transient information must be removed. To simulate only a single initial steady-state stress period, change the total number of stress periods to 1 . In this case, model stresses during the existing transient stress periods do not need to be removed as they are effectively turned off leaving only a single steady-state stress period. The observation files, the DIS file which specifies time discretization, and storage parameters in the HUF2 Package and SEN Process require editing. The OC Option also requires editing so that printing and saving does not occur from the transient stress periods that have been removed from the model simulation. Additionally, all observation packages ( $\mathrm{CHOB}, \mathrm{DROB}$, and $\mathrm{HOB})$ must be edited so that no observations are specified in times that extend beyond the period of the steady-state simulation. 
To convert the transient simulation to a steady-state simulation, specify a single steady-state stress period in the DIS file. If a single steady-state stress period is specified, the additional transient stress periods, which are specified on subsequent lines in the file, will not be read.

- In the DIS file (DIS_WT_CONFINED.txt), change the variable NPER to 1 to reflect a single steady-state stress period. For example, replace the 87 stress periods in DIS file:

\# DIS Package Line 0: Text

161941608742 Line 1: NLAY NROW NCOL NPER ITMUNI LENUNI

with a single steady state stress period as indicated by the gray highlighting:

\# DIS Package Line 0: Text

16194160142 Line 1: NLAY NROW NCOL NPER ITMUNI LENUNI.

To convert from a transient to a steady-state simulation, specific storage parameters (parameter types SS and SYTP) must be removed from the HUF2 Package (HUF2_CONFINED.txt) and the SEN Process (SENSITIVITY.txt) files. The removal of these parameters also must be reflected in the total number of HUF2 Package parameters (variable NPHUF) and the total number of parameters in the SEN Process (variables NPLIST and MXSEN). If the seven storage parameters (STOR_12, STOR_34, STOR_4VUP, STOR_4C, SY_OTHER, SY_PAH, and SY_PUMP) are removed from the HUF2 Package (lines 246 to 283) and the SEN Process (lines 97 to 103), the variable NPHUF, which specifies the total number of parameters in the HUF2 Package (HUF2_CONFINED.txt), also must decrease by seven (from 69 to 62) as indicated by the gray shading in the first data row in the HUF2 Package:

\# HUF2 Package

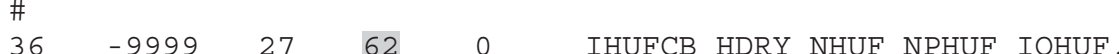

Additionally, the total number of parameters in the SEN Process must be decreased from 100 to 93 as indicated by the gray shading in the first data row.

\# SEN Package Line 0: Text (Line 3: PARNAM ISENS LN B BL BU BSCAL)

$93-1003$ Line 1: NPLIST ISENALL IUHEAD MXSEN

As steady-state conditions were defined as pre-development conditions with no pumping, the MNW Package should be deactivated in the name file.

In the OC Option, remove all references to stress periods after stress period 1.

- For example, in the OC Option (OC.txt) remove lines 14 to 27.

After the above editing is complete, model simulations will be executed with steady-state conditions if the OBS Process is deactivated in the name file. To run the model with steady-state conditions and an active OBS Process, edit the DROB and HOB Packages. The CHOB Package does not require editing because all observations occur during the steady-state stress period.

Most observations in the DROB Package are specified during stress period 86. Because only two discharge locations have flows that diminish with time, the observation flows in stress period 86 also reflect steady-state conditions, and only the observation time requires editing.

- In the DROB Package (drob_tr.txt), the observation flow and associated observation weight does not need to be changed; however, the time associated with each observation should be switched from stress period 86 to stress period 1 by changing the variable for the reference stress period (IREFSP) from 86 to 1. 


\section{A Guide for Using the Transient Ground-Water Flow Model of the DVRFS, Nevada and California}

For example, for the drain observation at Furnace Creek Wash springs in Death Valley (OBS-DV-FRNFN) highlighted below in gray, the change is from stress period 86 :

$\begin{array}{rrrrrrr}1 & 9 & & & & & \\ \text { OBS-DV-FRNFN } & & & 86 & -11522 . & 0.280 & 2 \\ 1 & 122 & 50 & & 1.00 & \\ 1 & 123 & 49 & 1.00 & \\ 1 & 123 & 50 & 1.00 & \\ 1 & 124 & 49 & 1.00 & \\ 1 & 124 & 50 & 1.00 & \\ 1 & 125 & 49 & 1.00 & \\ 1 & 125 & 50 & 1.00 & \\ 1 & 126 & 50 & 1.00 & \\ 1 & 126 & 51 & 1.00 & \end{array}$

to stress period 1 :

$\begin{array}{cccccc}1 & 9 & & & & \\ \text { OBS-DV-FRNFN } 1 & & 1 & -11522 . & 0.280 & 23 \\ 1 & 122 & 50 & & 1.00 & \\ 1 & 123 & 49 & 1.00 & \\ 1 & 123 & 50 & 1.00 & \\ 1 & 124 & 49 & 1.00 & \\ 1 & 124 & 50 & 1.00 & \\ 1 & 125 & 49 & 1.00 & \\ 1 & 125 & 50 & 1.00 & \\ 1 & 126 & 50 & 1.00 & \\ 1 & 126 & 51 & 1.00 & \end{array}$

Four drain observations at two locations (Manse and Bennetts Springs in Pahrump Valley), which reflect decreasing flows over time, must be removed as they do not reflect steady-state conditions: OB-PAH-BENT (stress period 48), O-PAH-BENT (stress period 87), OB-PAH-MANS (stress period 48), and O-PAH-MANS (stress period 87). The change in the total number of observations (from 49 to 45 ) must be reflected in the first data row of DROB Package.

- In the DROB Package (drob_tr.txt), remove observations O-PAH-BENT (lines 809-846), OB-PAH-BENT (lines 771808), OB-PAH-MANS (lines 861-874) and O-PAH-MANS (lines 875-888).

- In the DROB Package (drob_tr.txt), edit the total number of observations (variables NQDR and NQTDR) from 49 to 45. Thus the first data row of the file changes from:

\#Observations in the 1997=86 stress period and stress period 1.
$49 \quad 769 \quad 49$

to:

\#Observations in the 1997=86 stress period and stress period 1 .

$45 \quad 769 \quad 45$

as indicated by the gray highlighting.

In the HOB Package, remove observations that do not reflect steady-state conditions. This can be accomplished by removing hydraulic head observations with PLOT-SYMBOL values of 2 or 3 (so that just PLOT-SYMBOL values of 0 and 1 remain) or by deleting entries that occur at times other than during the steady-state stress period. Update the change in the total number of head and head change observations (variable NH) in the first data row of the HOB Package.

- In the HOB Package (HOBs_sstr.txt), remove observations that occur during the transient stress periods.

- In the HOB Package, update variable NH, the total number of head and head change observations.

After editing, execute MODFLOW-2000 in the forward mode with observations and parameter-value substitution (table 7). 


\section{Summary}

This guide informs the user about the files, structures, and parameters provided in the electronic resources of the transient DVRFS model. Input, output, and model simulation modes with MODFLOW-2000 of likely utility to the user are described. Input includes observation packages that contain observations of hydraulic head and head change, flows, and flows associated with groups of constant head cells along portions of the model boundary. The source of information and assumptions on which the observation values and weights are based is discussed. These observations provide model users a tool to evaluate model fit that is critical to analyzing any application of the DVRFS model. In addition to characterizing the input and output of the DVRFS model, the mechanics of creating such output is explored for several types of model modes: forward, parameter-sensitivity, and parameterestimation. For typical users of the DVRSF model, two common modifications of the model arise: predictive pumping scenarios and conversion of the model from a transient to a steady-state simulation. Editing of the model archive files to achieve both of these model modifications is outlined with examples.

\section{References Cited}

Anderman, E.R., and Hill, M.C., 2000, MODFLOW-2000, The U.S. Geological Survey modular ground-water flow model-Documentation of the hydrogeologic-unit flow (HUF) package: U.S. Geological Survey Open-File Report 00-342, 89 p.

Anderman, E.R., and Hill, M.C., 2003, MODFLOW-2000, The U.S. Geological Survey modular ground-water flow model-Three additions to the hydrogeologic-unit flow (HUF) package-Alternative storage for the uppermost active cells (STYP parameter type), flows in hydrogeologic units, and the hydraulic conductivity depth-dependence (KDEP) capability: U.S. Geological Survey OpenFile Report 03-347, 36 p. Accessed April 14, 2004 at http://water.usgs.gov/nrp/gwsoftware/modflow2000/ modflow2000.html.

Bedinger, M.S., and Harrill, J.R., 2004a, Appendix 1. Regional potential for interbasin flow of ground water, in Belcher, W.R., ed., Death Valley regional ground-water flow system, Nevada and California-Hydrogeologic framework and transient ground-water flow model: U.S. Geological Survey Scientific Investigations Report 2004-5205, p. 357-374. Accessed June 8, 2004 at http://pubs.water.usgs. gov/sir20045205/.
Bedinger, M.S., and Harrill, J.R., 2004b, Plate 1. Regional potential for interbasin flow of ground water in the Death Valley regional ground-water flow system area, Nevada and California, in Belcher, W.R., ed., Death Valley regional ground-water flow system, Nevada and CaliforniaHydrogeologic framework and transient ground-water flow model: U.S. Geological Survey Scientific Investigations Report 2004-5205.

Belcher, W.R., D’Agnese, F.A., and O’Brien, G. M., 2004, Chapter A. Introduction, in Belcher, W.R., ed., Death Valley regional ground-water flow system, Nevada and California-Hydrogeologic framework and transient ground-water flow model: U.S. Geological Survey Scientific Investigations Report 2004-5205, p. 7-19. Accessed April 13, 2004 at http://pubs.water.usgs.gov/sir20045205/.

D’Agnese, F.A., Faunt, C.C., Turner, A.K., and Hill, M.C., 1997, Hydrogeologic evaluation and numerical simulation of the Death Valley regional ground-water flow system, Nevada and California: U.S. Geological Survey WaterResources Investigations Report 96-4300, 124 p.

D’Agnese, F.A., O’Brien, G.M., Faunt, C.C., Belcher, W.R., and San Juan, C., 2002, A three-dimensional numerical model of predevelopment conditions in the Death Valley regional ground-water flow system, Nevada and California: U.S. Geological Survey Water-Resources Investigations Report 02-4102, 114 p.

Faunt, C.C., D’Agnese, F.A., and O'Brien G.M., 2004a, Chapter D. Hydrology, in Belcher, W.R., ed., Death Valley regional ground-water flow system, Nevada and California-Hydrogeologic framework and transient ground-water flow model: U.S. Geological Survey Scientific Investigations Report 2004-5205, p. 137-164. Accessed April 13, 2004 at http://pubs.water.usgs.gov/sir20045205/.

Faunt, C.C., Blainey, J.B., Hill, M.C., D’Agnese, F.A., and O'Brien, G.M., 2004b, Chapter F. Transient Numerical Model, in Belcher, W.R., ed., Death Valley regional groundwater flow system, Nevada and California-Hydrogeologic framework and transient ground-water flow model: U.S. Geological Survey Scientific Investigations Report 20045205, p. 257-352. Accessed April 13, 2004 at http://pubs. water.usgs.gov/sir20045205/.

Halford, K.J., and Hanson, R.T., 2002, User guide for the drawdown-limited, multi-node well (MNW) package for the U.S. Geological Survey's modular three-dimensional finitedifference ground-water flow model, versions MODFLOW96 and MODFLOW-2000: U.S. Geological Survey OpenFile Report 02-293, 33 p. 
Hanson, R.T., and Leake, S.A., 1999, Documentation of HYDMOD, a program for extracting and processing timeseries data from the U.S. Geological Survey's modular three-dimensional finite-difference ground-water flow model: U.S. Geological Survey Open-File Report 98-564, $57 \mathrm{p}$.

Harbaugh, A.W., 1990, A computer program for calculating subregional water budgets using results from the U.S. Geological Survey modular three-dimensional ground-water flow model: U.S. Geological Survey Open-File Report 90-392, 46 p. Accessed June 1, 2005 at http://water.usgs. gov/nrp/gwsoftware/zonebud2/zonebudget2.html.

Harbaugh, A.W., 1995, Direct solution package based on alternating diagonal ordering for the U.S. Geological Survey modular finite-difference ground-water flow model: U.S. Geological Survey Open-File Report 95-288, 46 p.

Harbaugh, A.W., and McDonald, M.G., 1996, User's documentation for MODFLOW-96, an update to the U.S. Geological Survey modular finite-difference ground-water flow model: U.S. Geological Survey Open-File Report 96-485, 56 p. Accessed June 1, 2005 at http://water.usgs. gov/software/modflow-96.html.

Harbaugh, A.W., Banta, E.R., Hill, M.C., and McDonald, M.G., 2000, MODFLOW-2000, The U.S. Geological Survey modular ground-water model - User guide to modularization concepts and the ground-water flow process: U.S. Geological Survey Open-File Report 00-92, 121 p.

Harrill, J.R., and Bedinger, M.S., 2004, Appendix 2. Estimated boundary flows, in Belcher, W.R., ed., Death Valley regional ground-water flow system, Nevada and CaliforniaHydrogeologic framework and transient ground-water flow model: U.S. Geological Survey Scientific Investigations Report 2004-5205, p. 375-408. Accessed April 13, 2004 at http://pubs.water.usgs.gov/sir20045205/.

Hevesi, J.A., Flint, A.L., and Flint, L.E., 2003, Simulation of net infiltration and potential recharge using a distributed parameter watershed model of the Death Valley region, Nevada and California: U.S. Geological Survey Water Resources Investigations Report 03-4090, 91 p.

Hill, M.C., 1990, Preconditioned conjugate-gradient 2 (PCG2), a computer program for solving ground-water flow equations: U.S. Geological Survey Water-Resources Investigations Report 90-4048, 43 p.

Hill, M.C., 1998, Methods and guidelines for effective model calibration: U.S. Geological Survey Water-Resources Investigations Report 98-4005, $90 \mathrm{p}$.

Hill, M.C., Banta, E.R., Harbaugh, A.W., and Anderman, E.R., 2000, MODFLOW-2000, The U.S. Geological Survey's modular ground-water flow model—User guide to the observation, sensitivity, and parameter-estimation procedures and three post-processing programs: U.S. Geological Survey Open-File Report 00-184, 209 p.
Hsieh, P.A., and Freckleton, J.R., 1993, Documentation of a computer program to simulate horizontal-flow barriers using the U.S. Geological Survey modular three-dimensional finite difference ground-water flow model: U.S. Geological Survey Open-File Report 92-477, 32 p.

IT Corporation, 1996, Underground test area subproject, Phase I, Data analysis task, volume VI-Groundwater flow model data documentation package: Las Vegas, Nev., Report ITLV/10972-181 prepared for the U.S. Department of Energy, 8 volumes, various pagination.

Laczniak, R.J., Smith, J.L., Elliott, P.E., DeMeo, G.A., Chatigyn, M.A., and Roemer, G.J., 2001, Ground-water discharge determined from estimates of evapotranspiration, Death Valley regional flow system, Nevada and California: U.S. Geological Survey Water-Resources Investigations Report 01-4195, 51 p.

McDonald, M.G., and Harbaugh, A.W., 1984, A modular three-dimensional finite difference ground-water flow model: U.S. Geological Survey Open-File Report 83-875, $528 \mathrm{p}$.

McDonald, M.G., and Harbaugh, A.W., 1988, A modular three-dimensional finite difference ground-water flow model: U.S. Geological Survey Techniques of Water Resources Investigations, Book 6, Chapter A1, 586 p.

Mehl, S.E., and Hill, M.C., 2001, MODFLOW-2000, the U.S. Geological Survey modular ground-water model - User guide to the LINK-AMG (LMG) Package for solving matrix equations using an algebraic multigrid solver: U.S. Geological Survey Open-File Report 01-177, 33 p.

Moreo, M.T., Halford, K.J., La Camera, R.J., and Laczniak, R.J., 2003, Estimated ground-water withdrawals from the Death Valley regional flow system, 1913-1998, Nevada and California: U.S. Geological Survey Water-Resources Investigations Report 03-4245, 28 p.

Poeter, E.P., and Hill, M.C., 1997, Inverse models: a necessary next step in ground-water modeling, Ground Water, v. 35, no. 2, p. 250-260.

San Juan, C.A., Belcher, W.R., Laczniak, R.J., and Putnam, H.M., 2004, Chapter C. Hydrologic components for model development, in Belcher, W.R., ed., Death Valley regional ground-water flow system, Nevada and CaliforniaHydrogeologic framework and transient ground-water flow model: U.S. Geological Survey Scientific Investigations Report 2004-5205, p. 99-136. Accessed April 13, 2004 at http://pubs.water.usgs.gov/sir20045205/.

Wilson, J.D., and Naff, R.L., 2004, The U.S. Geological Survey modular ground-water model - GMG linear equation solver package documentation: U.S. Geological Survey Open-File Report 2004-1261, 47 p. Accessed June 1, 2005 at http://water.usgs.gov/nrp/gwsoftware/ modflow2000/modflow2000.html.

Winston, R.B., 2000, Graphical user interface for MODFLOW, version 4: U.S. Geological Survey Open-File Report 00-315, 27 p. Accessed June 1, 2005 at http://water.usgs. gov/nrp/gwsoftware/GW Chart/GW Chart.html. 


\section{Appendix A: File Archive Documentation}

The model files described below can be obtained from http://pubs.water.usgs.gov/sir20045205/ and clicking on the link "Model Archive." Brief descriptions of the input and output files follow. Input files are identified separately from output files.

\author{
Input files: \\ BAS_active.txt - basic package \\ CHOB_15reg.txt - constant head observations \\ CHD_15reg_tr.txt - constant heads \\ DIS_WT_CONFINED.txt - discretization \\ DRN_tr.txt - drains (DRN package) \\ DROB_tr.txt - drain observations \\ HFB_final_tr.txt - horizontal-flow barriers \\ HOBs_sstr.txt - head observations \\ HUF2_CONFINED.txt - hydrogeologic unit flow \\ HOBS_sstr.hyd - hydmod \\ KDEP.txt - depth decay \\ MNW_withdrawal_1_7_20.txt - multinode well \\ MULT.txt - multiplier \\ NAME.txt - names of input and output files \\ OBS.txt - observation process \\ OC.txt - output control \\ PCG.txt - pcg solver \\ PES.txt - parameter estimation settings \\ RCH_tr.txt - recharge \\ SENSITIVITY.txt - sensitivity process (actually contains parameter \\ values)

\section{ZONE.txt - zones} \\ ibound1.asc - ibound array layer 1 (BAS6 package) \\ ibound2.asc - ibound array layer 2 (BAS6 package) \\ ibound 3.asc - ibound array layer 3 (BAS6 package) \\ ibound4.asc - ibound array layer 4 (BAS6 package) \\ ibound5.asc - ibound array layer 5 (BAS6 package) \\ ibound6.asc - ibound array layer 6 (BAS6 package) \\ ibound7.asc - ibound array layer 7 (BAS6 package) \\ ibound8.asc - ibound array layer 8 (BAS6 package) \\ ibound9.asc - ibound array layer 9 (BAS6 package) \\ ibound10.asc - ibound array layer 10 (BAS6 package) \\ ibound11.asc - ibound array layer 11 (BAS6 package) \\ ibound12.asc - ibound array layer 12 (BAS6 package) \\ ibound13.asc - ibound array layer 13 (BAS6 package) \\ ibound14.asc - ibound array layer 14 (BAS6 package) \\ ibound15.asc - ibound array layer 15 (BAS6 package) \\ ibound16.asc - ibound array layer 16 (BAS6 package) \\ hd_lay1.asc - starting heads layer 1 (BAS6 package) \\ hd_lay2.asc - starting heads layer 2 (BAS6 package) \\ hd_lay3.asc - starting heads layer 3 (BAS6 package) \\ hd_lay4.asc - starting heads layer 4 (BAS6 package) \\ hd_lay5.asc - starting heads layer 5 (BAS6 package) \\ hd_lay6.asc - starting heads layer 6 (BAS6 package) \\ hd_lay7.asc - starting heads layer 7 (BAS6 package) \\ hd_lay8.asc - starting heads layer 8 (BAS6 package) \\ hd_lay9.asc - starting heads layer 9 (BAS6 package) \\ hd_lay10.asc - starting heads layer 10 (BAS6 package) \\ hd_lay11.asc - starting heads layer 11 (BAS6 package) \\ hd_lay12.asc - starting heads layer 12 (BAS6 package) \\ hd_lay13.asc - starting heads layer 13 (BAS6 package) \\ hd_lay14.asc - starting heads layer 14 (BAS6 package)
}

hd_lay15.asc - starting heads layer 15 (BAS6 package)

hd_lay16.asc - starting heads layer 16 (BAS6 package)

delr.txt - row spacing (DIS package)

delc.txt - column spacing (DIS package)

lay1_wt_sim.asc - top of layer 1 (DIS package)

lay2_top.asc - top of layer 2 (DIS package)

lay3_top.asc - top of layer 3 (DIS package)

lay4_top.asc - top of layer 4 (DIS package)

lay5_top.asc - top of layer 5 (DIS package)

lay6_top.asc - top of layer 6 (DIS package)

lay7_top.asc - top of layer 7 (DIS package)

lay8_top.asc - top of layer 8 (DIS package)

lay9_top.asc - top of layer 9 (DIS package)

lay10_top.asc - top of layer 10 (DIS package)

lay11_top.asc - top of layer 11 (DIS package)

lay12_top.asc - top of layer 12 (DIS package)

lay13_top.asc - top of layer 13 (DIS package)

lay14_top.asc - top of layer 14 (DIS package)

lay15_top.asc - top of layer 15 (DIS package)

lay16_top.asc - top of layer 16 (DIS package)

lay16_bot.asc - bottom of layer 16 (DIS package)

rch1_modmd.asc - multiplier array used to represent initial recharge

(MULT package)

land_surface.asc - land surface (used for depth decay) (KDEP file)

lca_zone.asc - zone array (ZONE package)

lccu_zone.asc - zone array (ZONE package)

vsu_zone.asc - zone array (ZONE package)

cald_zone.asc - zone array (ZONE package)

ovu_zone.asc - zone array (ZONE package)

infil_zone_9.asc - zone array (ZONE package)

tmva_zone.asc - zone array (ZONE package)

vsu_up_zone.asc - zone array (ZONE package)

xcu_zone.asc - zone array (ZONE package)

chvu_zone.asc - zone array (ZONE package)

cfbcu_zone.asc - zone array (ZONE package)

bru_zone.asc - zone array (ZONE package)

sy_zone.asc - zone array (ZONE package)

pva_zone.asc - zone array (ZONE package)

lca_modt.asc hydrogeologic unit top (HUF2 package)

lca_thickt.asc hydrogeologic unit thickness (HUF2 package)

lca_t1_modt.asc hydrogeologic unit top (HUF2 package)

lca_t1_thickt.asc hydrogeologic unit thickness (HUF2 package)

lccu_modt.asc hydrogeologic unit top (HUF2 package)

lccu_thickt.asc hydrogeologic unit thickness (HUF2 package)

lccu_t1_modt.asc hydrogeologic unit top (HUF2 package)

lccu_t1_thickt.asc hydrogeologic unit thickness (HUF2 package)

lfu_modt.asc hydrogeologic unit top (HUF2 package)

lfu_thickt.asc hydrogeologic unit thickness (HUF2 package)

ovu_modt.asc hydrogeologic unit top (HUF2 package)

ovu_thickt.asc hydrogeologic unit thickness (HUF2 package)

pva_modt.asc hydrogeologic unit top (HUF2 package)

pva_thickt.asc hydrogeologic unit thickness (HUF2 package)

oacu_modt.asc hydrogeologic unit top (HUF2 package) 


\section{Input Files_Continued}

oacu_thickt.asc hydrogeologic unit thickness (HUF2 package) tmva_modt.asc hydrogeologic unit top (HUF2 package) tmva_thickt.asc hydrogeologic unit thickness (HUF2 package) chvu_modt.asc hydrogeologic unit top (HUF2 package) chvu_thickt.asc hydrogeologic unit thickness (HUF2 package) cfta_modt.asc hydrogeologic unit top (HUF2 package) cfta_thickt.asc hydrogeologic unit thickness (HUF2 package) cfbcu_modt.asc hydrogeologic unit top (HUF2 package) cfbcu_thickt.asc hydrogeologic unit thickness (HUF2 package) cfppa_modt.asc hydrogeologic unit top (HUF2 package) cfppa_thickt.asc hydrogeologic unit thickness (HUF2 package) yvu_modt.asc hydrogeologic unit top (HUF2 package) yvu_thickt.asc hydrogeologic unit thickness (HUF2 package) yacu_modt.asc hydrogeologic unit top (HUF2 package) yacu_thickt.asc hydrogeologic unit thickness (HUF2 package) uca_modt.asc hydrogeologic unit top (HUF2 package) uca_thickt.asc hydrogeologic unit thickness (HUF2 package) uccu_modt.asc hydrogeologic unit top (HUF2 package) uccu_thickt.asc hydrogeologic unit thickness (HUF2 package) yaa_modt.asc hydrogeologic unit top (HUF2 package) yaa_thickt.asc hydrogeologic unit thickness (HUF2 package) xcu_modt.asc hydrogeologic unit top (HUF2 package) xcu_thickt.asc hydrogeologic unit thickness (HUF2 package) wvu_modt.asc hydrogeologic unit top (HUF2 package) wvu_thickt.asc hydrogeologic unit thickness (HUF2 package) la_modt.asc hydrogeologic unit top (HUF2 package) la_thickt.asc hydrogeologic unit thickness (HUF2 package) oaa_modt.asc hydrogeologic unit top (HUF2 package) oaa_thickt.asc hydrogeologic unit thickness (HUF2 package) vsu_low_modt.asc hydrogeologic unit top (HUF2 package) vsu_low_thickt.asc hydrogeologic unit thickness (HUF2 package) scu_modt.asc hydrogeologic unit top (HUF2 package) scu_thickt.asc hydrogeologic unit thickness (HUF2 package) bru_modt.asc hydrogeologic unit top (HUF2 package) bru_thickt.asc hydrogeologic unit thickness (HUF2 package) vsu_up_modt.asc hydrogeologic unit top (HUF2 package) vsu_up_thickt.asc hydrogeologic unit thickness (HUF2 package) icu_modt.asc hydrogeologic unit top (HUF2 package) icu_thickt.asc hydrogeologic unit thickness (HUF2 package)

\section{Output files:}

GLOBAL.txt - MF2K output file that contains information that applies to the model simulation as a whole

LIST.txt - MF2K output file that contains output from the procedures of the flow process (such as model results - hydraulic head, drawdown, and volumetric budget)

WELL_PACKAGE.wl1 - well package generated given current model parameters based on multi-node well process

CBCF.bin - binary cell by cell flow values (values written depend on flags in other files)

HEADSOUT.txt - simulated heads by layer and time specified in output control file

DRAWDOUT.txt - simulated drawdown by layer and time specified in output control file

HYDROGRAPHS.sav - binary output for hydrographs (used by HYDMOD)

dvr._b - output derived from observation process (output depends on flags in PES file)

dvr._nm - output derived from observation process (weighted residuals and probability plotting)

dvr._os - output derived from observation process (unweighted simulated equivalents and observations)

dvr._r - output derived from observation process (unweighted residuals)

dvr._w - output derived from observation process (weighted residuals)

dvr._ws - output derived from observation process (weighted simulated equivalents and residuals)

dvr._ww - output derived from observation process (weighted simulated equivalents and observations) 
For more information concerning the research in this report, contact Director, Nevada Water Science Center

U.S. Geological Survey

2730 N. Deer Run Road

Carson City, Nevada 89701

http://nevada.usgs.gov/ 


\section{$\mathbb{Z}$ 总}

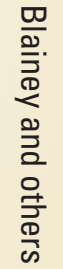

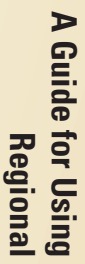

목 훙

컿

产就.

善

끙 몽

为

空

眾

늠 끙

ฮิ

흥

흘흥

옹

흘 훙

흥. 용

产 